\title{
A multi-model study of impacts of climate change on surface ozone in Europe
}

\author{
J. Langner ${ }^{1}$, M. Engardt ${ }^{1}$, A. Baklanov ${ }^{2}$, J. H. Christensen ${ }^{3}$, M. Gauss ${ }^{4}$, C. Geels ${ }^{3}$, G. B. Hedegaard ${ }^{3,8}$, R. Nuterman ${ }^{2}$, \\ D. Simpson ${ }^{4,5}$, J. Soares ${ }^{6}$, M. Sofiev ${ }^{6}$, P. Wind ${ }^{4,7}$, and A. Zakey ${ }^{2}$ \\ ${ }^{1}$ Swedish Meteorological and Hydrological Institute, 601 76, Norrköping, Sweden \\ ${ }^{2}$ Danish Meteorological Institute, Lyngbyvej 100, 2100, København Ø, Denmark \\ ${ }^{3}$ Department of Environmental Science, Aarhus University, 4000 Roskilde, Denmark \\ ${ }^{4}$ EMEP MSC-W, Norwegian Meteorological Institute, 0313 Oslo, Norway \\ ${ }^{5}$ Chalmers University of Technology, 41296 Gothenburg, Sweden \\ ${ }^{6}$ Finnish Meteorological Institute, P.O. Box 503, 00101 Helsinki, Finland \\ ${ }^{7}$ University of Troms $\varnothing$, 9037, Troms $\varnothing$, Norway \\ ${ }^{8}$ Centre for Environmental and Climate Research, Lund University, 22362 Lund, Sweden
}

Correspondence to: J. Langner (joakim.langner@smhi.se)

Received: 4 January 2012 - Published in Atmos. Chem. Phys. Discuss.: 13 February 2012

Revised: 20 September 2012 - Accepted: 1 November 2012 - Published: 8 November 2012

\begin{abstract}
The impact of climate change on surface ozone over Europe was studied using four offline regional chemistry transport models (CTMs) and one online regional integrated climate-chemistry model (CCM), driven by the same global projection of future climate under the SRES A1B scenario. Anthropogenic emissions of ozone precursors from RCP4.5 for year 2000 were used for simulations of both present and future periods in order to isolate the impact of climate change and to assess the robustness of the results across the different models. The sensitivity of the simulated surface ozone to changes in climate between the periods 2000 2009 and 2040-2049 differs by a factor of two between the models, but the general pattern of change with an increase in southern Europe is similar across different models. Emissions of isoprene differ substantially between different CTMs ranging from 1.6 to $8.0 \mathrm{Tg} \mathrm{yr}^{-1}$ for the current climate, partly due to differences in horizontal resolution of meteorological input data. Also the simulated change in total isoprene emissions varies substantially across models explaining part of the different climate response on surface ozone. Ensemble mean changes in summer mean ozone and mean of daily maximum ozone are close to $1 \mathrm{ppb}(\mathrm{v})$ in parts of the land area in southern Europe. Corresponding changes of 95-percentiles of hourly ozone are close to $2 \mathrm{ppb}(\mathrm{v})$ in the same region. In northern Europe ensemble mean for mean and daily max-
\end{abstract}

imum show negative changes while there are no negative changes for the higher percentiles indicating that climate impacts on $\mathrm{O}_{3}$ could be especially important in connection with extreme summer events.

\section{Introduction}

Despite significant control efforts, air pollution is still a major problem in Europe. During the last decades, target values have been frequently exceeded for ozone $\left(\mathrm{O}_{3}\right)$, nitrogen dioxide $\left(\mathrm{NO}_{2}\right)$ and $\mathrm{PM}_{10}$ in many European cities, and for $\mathrm{O}_{3}$ also in rural areas (EEA, 2003). Changing patterns of temperature, wind and precipitation will affect the chemistry of air pollutants, their emission, transport, concentration, deposition, exposure and effects (DEFRA, 2007; Andersson et al., 2007; Ellingsen et al., 2008; Hedegaard et al., 2008; Isaksen et al., 2009 and references therein; Royal society, 2008). Conversely changes in concentrations of air pollutants can also affect the radiation balance and emissions of particulate matter can have impacts on the radiative properties and life cycle of clouds (IPCC, 2007). The Nordic countries and the Arctic region are affected by long-range transport of air pollutants from the main source regions in continental Europe. Changes in atmospheric circulation due to climate change

Published by Copernicus Publications on behalf of the European Geosciences Union. 
can therefore affect future levels of air pollution and deposition (see e.g. AMAP, 2011). Changes in meteorological conditions can also influence local dispersion and deposition conditions to vegetation and thereby influence the effects of both long-range transported and locally emitted air pollutants on human health and ecosystems.

The link between climate change and air pollution in $\mathrm{Eu}-$ rope has been assessed in several recent studies using regional CTMs (e.g. Langner et al., 2005; Forkel and Knoche, 2006, 2007; Meleux et al., 2007; Giorgi and Meleux, 2007; Hedegaard et al., 2008; Andersson and Engardt, 2010; Katragkou et al., 2011). Model assessments of air quality responding to a changing future climate indicate that some parts of Europe are expected to typically be both warmer and have higher $\mathrm{O}_{3}$ levels. $\mathrm{O}_{3}$ impacts on vegetation and tree growth may increase in a warmer and more humid climate due to changes in growing season and increased stomatal uptake (also in view of rising background $\mathrm{O}_{3}$ concentrations, e.g. Ashmore, 2005). Impaired photosynthesis and biomass accumulation can also lead to reduced carbon sequestration (Sitch et al., 2007).

Regional offline atmospheric chemistry models, CTMs, have been developed for European applications for more than three decades and have been used extensively as tools to provide a basis for decisions on successful emission controls of sulfur, nitrogen and volatile organic compounds in Europe. Despite this long development there is still considerable uncertainty in model predictions of air quality and deposition in Europe due to incomplete scientific knowledge about basic processes and model approximations and insufficient or poor quality input data. Recently a new generation of online integrated climate-chemistry models are being applied for Europe (EuMetChem, http://www.eumetchem.info/). A number of models with various levels of online coupling between the chemistry and atmospheric dynamics have been developed to investigate the interactions between climate and air quality (Zhang, 2008; Alapaty et al., 2011). Online models directly transmit meteorological fields produced by the climate model to a chemistry module, calculate the concentration of climate-relevant tracers and further (at the same time step) deliver these fields back to calculate their feedbacks on the meteorological fields. The radiative forcing of these tracers then feeds back into the climate model to affect temperatures and regional circulation. Computational constraints and physical/chemical complexity has prevented the widespread implementation of high-resolution, global coupled climatechemistry models for long-term climate integrations. To date, only a few regional climate models (RCMs) include online coupling with a range of chemical complexity (Giorgi et al., 2002; Solmon et al., 2006; Jacobson et al., 2007; Zhang et al., 2010; Shalaby et al., 2012).

Several multi-model studies of atmospheric chemistry and long-range transport of air pollution in Europe have been carried out over the last decade (e.g. Vautard et al., 2006, 2007, 2009; van Loon et al., 2007; Cuvelier et al., 2007; Thunis et al., 2007; Colette et al., 2011). These studies have focused on establishing the robustness of model predictions in the present climate. Here we, for the first time, assess the combined uncertainty of predicting the future climate and predicting the atmospheric chemistry and long-range transport of $\mathrm{O}_{3}$ over Europe. This study takes a multi-model approach using four state-of-the-art offline CTMs and one online integrated climate-chemistry model (CCM) to assess the uncertainty/robustness of model predictions of future surface $\mathrm{O}_{3}$ over Europe. Specifically we want to evaluate the sensitivity of simulated surface $\mathrm{O}_{3}$ concentrations to changes in climate. In order to facilitate the analysis of differences between models, and isolate the impacts of meteorological changes, we have chosen to keep anthropogenic emissions at current levels. This choice also enables comparison to earlier studies using single CTMs and a similar setup. A full assessment of future surface $\mathrm{O}_{3}$ concentrations also needs to take into account changes in anthropogenic emissions. This will be the target for future studies using the present model ensemble.

\section{Methods}

The model chain used in this study is illustrated in Fig. 1. The chain starts with the selection of a socio-economic emission scenario which is fed into a global climate model, GCM, to generate a climate projection. The same global climate projection has been the basis for all the hemispheric and regional scale simulations performed in this study. The meteorological data from the GCM are then used in an offline hemispheric chemical transport model, CTM, and as boundaries in a regional climate model, RCM. The output from the hemispheric CTM and the RCM is finally used to drive regional offline CTMs for the European domain. Emissions of anthropogenic $\mathrm{O}_{3}$ precursors from the same data base are fed both into the hemispheric CTM and the regional CTMs. In this study we have also utilized one online climate-chemistry model which simulates its own regional climate using the GCM climate and hemispheric CTM output on its boundaries. Two 10-yr time periods were studied, a reference period, 2000-2009, and a future period, 2040-2049.

\subsection{Climate projection}

The climate projection used in this study is from the ECHAM5 model (Roeckner et al., 2006a, b, c). The RCM used to downscale the GCM projection is the Rossby Centre Regional Climate model version 3, RCA3. Model description and evaluation of different aspects of both current and future climate simulated with RCA3 is given by Samuelsson et al. (2011) and Kjellström et al. (2011). The projection used here is the downscaling named ECHAM5 A1B-r3 by Kjellström et al. (2011). The climate projection was derived using the SRES A1B emission scenario (Nakićenović et al., 2000). Six-hourly meteorological output on 21 model levels as well 


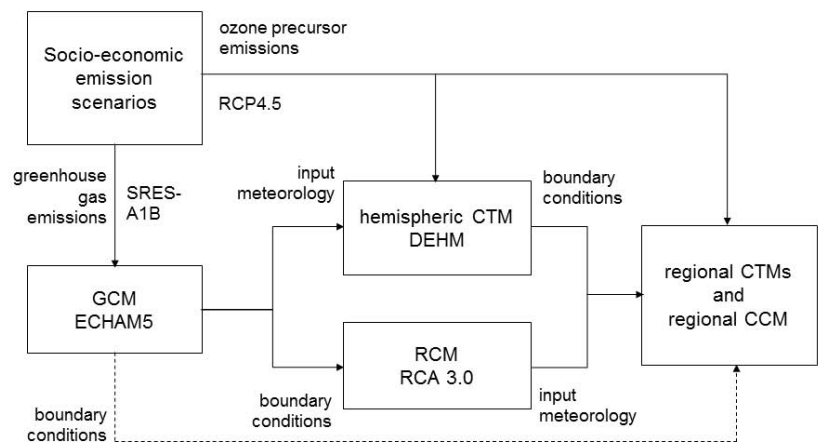

Fig. 1. Model chain used in the study.

as a range of output variables at the surface were stored from the RCA3 simulations to be used in the offline CTM modelling. The horizontal resolution of RCA3 was $0.44^{\circ} \times 0.44^{\circ}$ (ca. $50 \times 50 \mathrm{~km}^{2}$ ) on a rotated latitude longitude grid.

The climate as downscaled by RCA 3 carries on broad features of the climate simulated by the parent GCM. The average temperature change in the period 2000-2040 for the European model domain in the downscaled ECHAM5 A1B-r3 is $1.27^{\circ} \mathrm{C}$. This climate projection has a temperature change until the period 2041-2070 close to the average of an ensemble of 16 different projections downscaled from different GCM runs by RCA3 over Europe (Kjellström et al., 2011). The mean absolute error for temperature and precipitation over land areas for June-August for the period 1961-1990 is $1.05 \mathrm{~K}$ and $38.9 \%$ respectively when comparing to observations (Kjellström et al., 2011). The corresponding biases when forcing RCA3 with ERA40 on the boundaries are $0.60 \mathrm{~K}$ and $41.3 \%$. Figure 2 shows the change between 2000-2009 and 2040-2049 for April-September in two meter temperature, precipitation, sunshine duration and relative humidity at two meter simulated by RCA3. Apart from increases in temperature the climate projection shows an increase in summer precipitation in large parts of northern Europe extending also over Poland and Germany while precipitation generally decrease in southern Europe. Connected to this is also a summer decrease in sunshine duration in northern Europe and increase in southern Europe with a similar spatial pattern as for precipitation. Changes in relative humidity at the surface also show a similar pattern, but in addition relative humidity also generally increases over the oceans including the Mediterranean.

\subsection{Emission data}

Anthropogenic emissions of nitrogen oxides $\left(\mathrm{NO}_{\mathrm{x}}\right)$, sulfur dioxide $\left(\mathrm{SO}_{2}\right)$, ammonia $\left(\mathrm{NH}_{3}\right)$, non-methane hydrocarbons (NMVOC) and carbon monoxide (CO) used in all model simulations were taken from the RCP4.5 scenario (Thomson et al., 2011). The RCP scenarios have been developed as a replacement of the SRES scenarios and are now the basis for
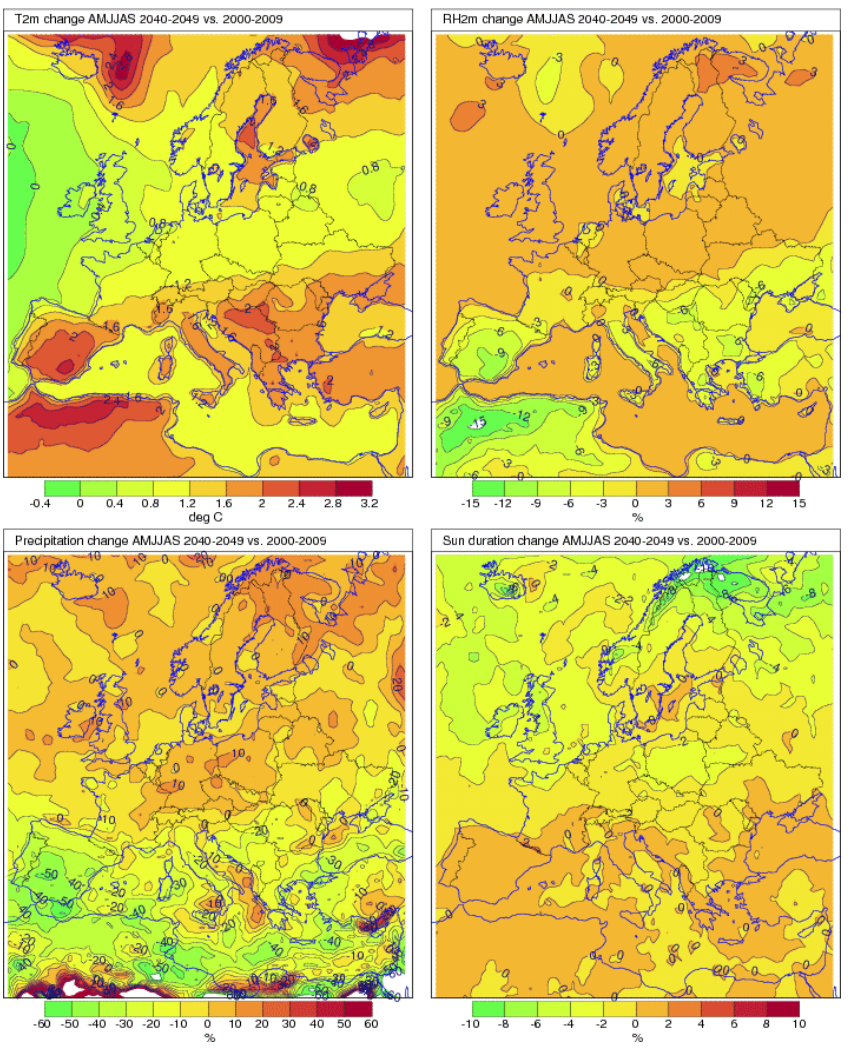

Fig. 2. Simulated April-September change 2000-2009 to 2040 2049 in two meter temperature, precipitation, sunshine duration and relative humidity at two meter simulated by RCA3. Units ${ }^{\circ} \mathrm{C}$ and $\%$.

current modelling activities in the climate modelling community. In this study we used constant emissions for year 2000 which are actually based on historic information (Lamarque et al., 2010). The specification for the model runs stipulated that the same annual anthropogenic emissions from the RCP4.5 should be used. The process for interpolating the data is however model specific. All models except EnvClimA employed, monthly, daily and hourly cycles to describe the temporal variation of the emissions. In the vertical all models allocated emissions throughout the bottom layers of the models according to their SNAP sectors.

Biogenic emissions of isoprene $\left(\mathrm{C}_{5} \mathrm{H}_{8}\right)$ were implemented differently in the different CTMs (see model descriptions below) and therefore resulted in different emissions. This involves also the use of different databases for land-use and vegetation. Figure 3 shows the seasonal variation of the emissions simulated in different models as an average for the reference period. The seasonality of emissions is similar with highest emissions in July except for MATCH which have the highest emissions in August. Three global models presented by Arneth et al. (2011) also displayed a maximum in July. Table 1 summarizes the emissions of isoprene in the models averaged for the reference and future periods. As can be seen emissions increase with time as the climate gets warmer. In 
Table 1. Annual biogenic emissions of isoprene in models.

\begin{tabular}{lll}
\hline Model & $\begin{array}{l}\text { Emission }\left(\mathrm{Gg} \mathrm{yr}^{-1}\right) \\
\text { 2000-2009 }\end{array}$ & $\begin{array}{l}\text { Emission }\left(\mathrm{Gg} \mathrm{yr}^{-1}\right) \\
2040-2049\end{array}$ \\
\hline DEHM & 8018 & 9910 \\
EnvClimA & $125^{*}$ & $125^{*}$ \\
EMEP & 3405 & 4114 \\
SILAM & 4080 & 5139 \\
MATCH & 1592 & 1917 \\
\hline
\end{tabular}

* Isoprene emissions from forest fires and biomass burning (RCP 4.5) was included in the EnvClimA simulations.

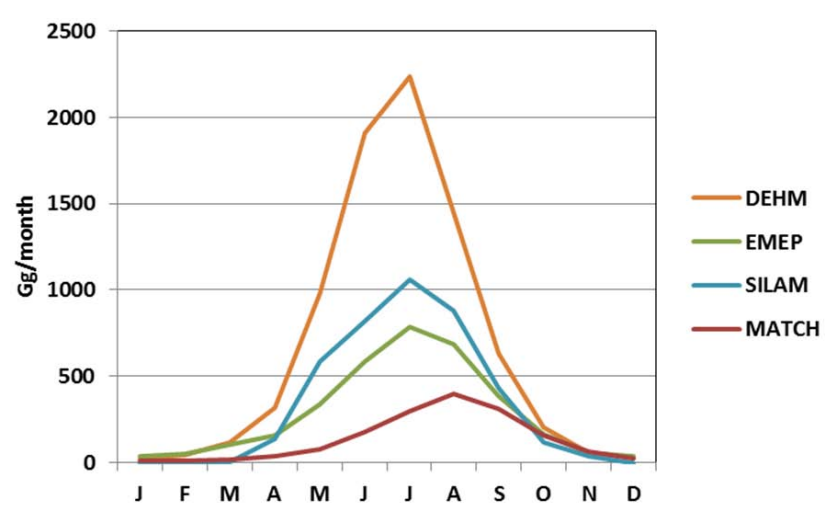

Fig. 3. Simulated seasonal variation in biogenic isoprene emissions as an average for 2000-2009. Units Gg month ${ }^{-1}$.

all of the models except for EnvClimA, changes of temperature and solar radiation drive the $\mathrm{C}_{5} \mathrm{H}_{8}$ emission changes. None of the models accounts for the possible inhibiting effect of $\mathrm{CO}_{2}$ changes or changes in land-use as discussed by e.g. Arneth et al. (2007) and Latheière et al. (2010). Differences between the models are about a factor of five and illustrate the current large uncertainty in predictions of isoprene emissions over Europe. Similar problems have been found on larger scales: in an ensemble with global CTMs the global total of isoprene emissions ranged $220-631 \mathrm{TgC} \mathrm{yr}^{-1}$ (Stevenson et al., 2006). The reliability of the empiricallybased methods used in the different models is conditioned by the availability of measurements and there are considerable uncertainties in predicting changes under environmental conditions outside the range used to derive the empirical models (Pacifico et al., 2009).

Apart from differences in methodology differences in the temperature fields used in the model simulations also has a large effect for the simulated isoprene emissions. The temperature fields used in DEHM has a much coarser horizontal resolution compared to the fields derived from the downscaling by the RCM used by the other CTMs, Fig. 4. This means that the topography is much smoother in the global data resulting in higher temperatures in areas with substantial topography. The global model data also shows a broader maximum in southern Europe while the data downscaled by
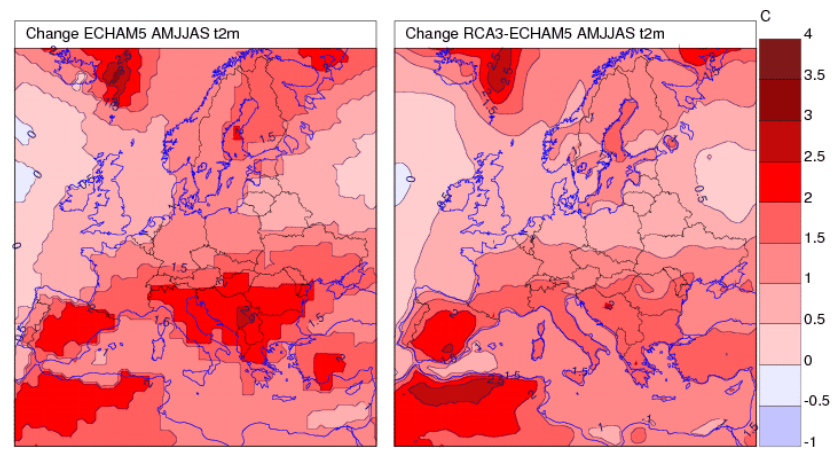

Fig. 4. Temperature change between the periods 2000-2009 and 2040-2049 for April-September simulated with ECHAM5 A1B-r3 (left) and downscaling of the same simulation with RCA3 (right). Units: ${ }^{\circ} \mathrm{C}$.

RCA3 put the temperature change more over land (Fig. 4). The average temperature change for the whole grid is also larger in the original global data compared to the downscaled version by $0.12{ }^{\circ} \mathrm{C}$.

\subsection{Boundary conditions}

Chemical boundary conditions at lateral and top boundaries of the regional models for the following 22 chemical components were provided by the hemispheric DEHM model; $\mathrm{NO}, \mathrm{NO}_{2}, \mathrm{O}_{3}, \mathrm{CO}, \mathrm{HCHO}, \mathrm{PAN}, \mathrm{HNO}_{3}, \mathrm{H}_{2}$, $\mathrm{CH}_{4}, \mathrm{CH}_{3} \mathrm{CHO}, \mathrm{C}_{2} \mathrm{H}_{6}, \mathrm{C}_{5} \mathrm{H}_{8}, \mathrm{nC}_{4} \mathrm{H}_{10}$, o-Xylene, $\mathrm{SO}_{2}$, $\mathrm{NH}_{3}, \mathrm{~N}_{2} \mathrm{O}_{5}, \mathrm{SO}_{4}^{2-}$ (sulphate or sulphuric acid), $\mathrm{NH}_{4} \mathrm{NO}_{3}$, aerosol nitrate, $\mathrm{NH}_{4} \mathrm{HSO}_{4},\left(\mathrm{NH}_{4}\right)_{2} \mathrm{SO}_{4}$. Secondary inorganic aerosols were included in the boundary conditions in order to enable also a future study of nitrogen deposition. The boundary values taken from DEHM were updated every 6 hours and interpolated from the DEHM resolution to the respective geometry of each regional CTM. However, the online integrated climate-chemistry model EnvClimA which was run on a larger model domain used monthly mean boundary conditions from DEHM. To ensure consistency, the offline DEHM model was operated with global ECHAM5 A1B-r3 meteorology and also using the global RCP4.5 emissions valid for year 2000. Boundary conditions for other chemical components were specified by each modelling group as their best estimate of the model boundary at ca. 2000 . The vertical discretization differs between the different models. The EnvClimA, EMEP, SILAM and MATCH models use vertically interpolated lateral chemical boundary conditions calculated by the DEHM model. In EMEP, SILAM and MATCH the data from DEHM is also used to set boundary conditions at the top of the model domain and therefore reflect the stratosphere-troposphere exchange simulated by this model while EnvClimA includes both the troposphere and the lower and middle stratosphere and therefore treat transport of stratospheric ozone to the troposphere internally. 


\subsection{Model descriptions}

\subsubsection{The DEHM model}

The Danish Eulerian Hemispheric Model (DEHM) is a threedimensional, Eulerian, CTM (Christensen, 1997; Frohn et al., 2002a, b; Frohn, 2004; Brandt, 2012) developed at the Danish National Environmental Research Institute (now Aarhus University). The model domain covers most of the Northern Hemisphere, discretized on a polar stereographic projection, and includes the possibility of a two-way nesting procedure with several nests with higher resolution over Europe, Northern Europe and Denmark (Frohn et al., 2002a). The boundary conditions depend on the wind direction. Free boundary conditions are used for areas where mass is transported out of the domain and elsewhere the boundary conditions are set to an annual average background value. For $\mathrm{O}_{3}$, the initial and boundary conditions are based on ozonesonde measurements, interpolated to global monthly 3-D values with a resolution of $4 \times 5$ degrees (Logan, 1999).

Originally DEHM is based on a chemical scheme by Strand and Hov (1994), which has been extended with a detailed description of the ammonia chemistry through the inclusion of $\mathrm{NH}_{3}$ and related species: ammonium nitrate $\left(\mathrm{NH}_{4} \mathrm{NO}_{3}\right)$, ammonium bisulphate $\left(\mathrm{NH}_{4} \mathrm{HSO}_{4}\right)$, ammonium sulphate $\left(\left(\mathrm{NH}_{4}\right)_{2} \mathrm{SO}_{4}\right)$ and particulate nitrate $\left(\mathrm{NO}_{3}^{-}\right)$formed from nitric acid $\left(\mathrm{HNO}_{3}\right)$. Furthermore, reactions concerning the aqueous phase production of particulate sulphate have been included. Several of the original photolysis rates as well as rates for inorganic and organic chemistry have been updated with rates from the chemical scheme applied in the EMEP model (Simpson et al., 2003a). The current model version includes 58 gas phase chemical compounds (including $\mathrm{NO}_{\mathrm{x}}, \mathrm{SO}_{\mathrm{x}}, \mathrm{NMVOC}, \mathrm{NH}_{\mathrm{x}}, \mathrm{CO}$, etc.) and 9 classes of particulate matter $\left(\mathrm{PM}_{2.5}, \mathrm{PM}_{10}\right.$, TSP, sea-salt $<2.5 \mu \mathrm{m}$, seasalt $>2.5 \mu \mathrm{m}$, smoke from wood stoves, fresh black carbon, aged black carbon, and organic carbon). One of the particle classes, the fraction of sea-salt $<2.5 \mu \mathrm{m}$, is not included in this version of the model. DEHM includes 122 chemical reactions.

Dry deposition is parameterized similar to the EMEP model (Simpson et al., 2003b; Emberson, 2000) except for the dry deposition of species on water surfaces where the deposition depends on the solubility of the chemical specie and the wind speed (Asman et al., 1994; Hertel et al., 1995). Wet deposition includes in-cloud and below-cloud scavenging and is calculated as the product of scavenging coefficients and the concentration.

The natural emissions of VOCs (isoprene) are calculated dynamically in the model according to the IGAC-GEIA biogenic emission model (International Global Atmospheric Chemistry - Global Emission Inventory Activity) (Guenther et al., 1995). Besides isoprene, other naturally emitted VOCs like for example terpenes are not included in the current model version. Natural emissions of $\mathrm{NO}_{\mathrm{x}}$ from lightning and soil as well as natural emissions of $\mathrm{NH}_{3}$ from soil/vegetation based on GEIA (Global Emission Inventory Activity) are also included. In the model run used as boundary conditions for the other CTMs (Fig. 1) also natural emissions from biomass burning was included.

Evaluation of the DEHM model for previous simulations of surface ozone can be found in Geels et al. (2005), Hedegaard et al. (2008) and Brandt et al. (2012).

\subsubsection{The DMI modelling framework}

In this study the DMI online integrated climate-chemistry model (EnvClimA) has been applied considering the ozone feedback on meteorology. The EnvClimA is a new online climate-chemistry model based on the International Centre for Theoretical Physics (ICTP) regional climate model (RegCM-CHEM4, Shalaby et al., 2012). The updated version of the EnvClimA model includes aerosol-chemistrydynamics modules and a new cloud scheme as well as the direct and indirect aerosol effects. EnvClimA is considered as the climate version of Enviro-HIRLAM. The dynamical core of EnvClimA is that of RegCM and does not include, in comparison with Enviro-HIRLAM, the NWP rerunning and data assimilation routines, making it computationally faster and more efficient for climate studies. Both EnvClimA and Enviro-HIRLAM use the same aerosol-chemistry, gasphase chemistry, feedbacks and cloud scheme. However, in this study only gas-phase species and their direct effects on meteorological variables were considered. The main differences between the EnvClimA and RegCM4-CHEM are that photolysis rates are calculated by different methods and that ozone feedback on the meteorology is not taken into account in RegCM4-CHEM yet, while it is considered in EnvClimA.

Tropospheric gas-phase chemistry is integrated into the climate model using the condensed version of the Carbon Bond Mechanism (CBM-Z; Zaveri and Peters, 1999) with lumped species that represent broad categories of organics based on carbon bond structure with a fast Radical Balance Method (RBM). The computationally rapid RBM of Sillman (1991) and Barth et al. (2003) is coupled as a chemical solver to the gas-phase mechanism. Photolysis rates are determined as a function of meteorological and chemical inputs and interpolated from an array of pre-determined values based on the Tropospheric Ultraviolet-Visible Model (Madronich and Flocke, 1999) with cloud cover corrections by (Chang et al., 1987). Cloud optical depths and cloud altitudes from EnvClimA are used in the photolysis calculations, thereby directly coupling the photolysis rates and chemical reactions to meteorological conditions at each model time step.

Dry deposition velocities for 31 gaseous species are calculated from a "big leaf" multiple resistance model (Wesely, 1989; Zhang et al., 2002, 2003) with aerodynamic, quasilaminar layer, and surface resistance acting in series. The processes assume 20 land-use types and make a distinction 
between uptake resistance for vegetation, soil, water, snow and ice. In the dry deposition scheme we consider both stomata and non-stomata resistances, which are necessary as the stomata uptake occurs only during the daytime for most chemical species. The aerodynamic resistance is calculated from the model boundary layer stability, wind speed and surface roughness, where a quasi-laminar surface layer is incorporated.

In the current simulations of EnvClimA biogenic isoprene emissions were not considered. The isoprene emission using the MEGAN module (Guenther et al., 2006), which is online coupled with the land surface model in EnvClimA, is believed to be too high (Rinne et al., 2009). Half of the emitted isoprene emission from MEGAN would give reasonable results for $\mathrm{O}_{3}$ concentrations. We are in the processes to improve this issue as future work in the model. Because EnvClimA is a limited-area model, meteorological lateral boundary forcings are required. For the present and future simulation here, initial and lateral boundary conditions for the meteorological fields are provided by the global model ECHAM5 A1B-r3 every six hours.

\subsubsection{The EMEP/MSC-W model}

The EMEP MSC-W model is a CTM developed at the EMEP Meteorological Synthesizing Centre-West (EMEP MSC-W) at the Norwegian Meteorological Institute. The model is a development of the 3-D model of Berge and Jakobsen (1998), extended with photo-oxidant and aerosol chemistry (Andersson-Sköld and Simpson, 1999; Simpson et al., 2012).

The methodology for biogenic emissions used in the EMEP model has undergone a substantial update during 2011, now building upon maps of 115 forest species generated by Köble and Seufert (2001). Emission factors for each forest species and for other land-classes are based upon Simpson et al. (1999), updated with recent literature (see Simpson et al. (2012) and references therein), and driven by hourly temperature and light using algorithms from Guenther et al. (1995). Other natural emissions include marine emissions of dimethlysulfide, and $\mathrm{SO}_{2}$ from volcanoes.

Dry deposition is calculated using a resistance analogy combined with stomatal and non-stomatal conductance algorithms (e.g. Simpson et al., 2003a; Tuovinen et al., 2004), whereas wet deposition uses scavenging coefficients applied to the 3-D rainfall. The model has traditionally been used at $50 \times 50 \mathrm{~km}^{2}$ resolution over Europe, but is flexible with respect to input meteorological data and domain, with applications ranging from $5 \times 5 \mathrm{~km}^{2}$ over the UK (Vieno et al., 2010) to $1^{\circ} \times 1^{\circ}$ globally (Jonson et al, 2010a, b). Full details and evaluation of the EMEP model are given in Simpson et al. (2012).

\subsubsection{The SILAM model}

The modelling tool used in this study is the System for Integrated modeLling of Atmospheric coMposition, SILAM (Sofiev et al., 2006, 2008). Its dynamic core currently includes both Eulerian and Lagrangian advection-diffusion formulations. The Eulerian core used in the current study is based on the transport scheme of Galperin (2000) which incorporates the horizontal diffusion term and is combined with the extended resistance analogy of Sofiev (2002) for vertical diffusion. The system includes a meteorological preprocessor for evaluation of basic features of the boundary layer and the free troposphere using the meteorological fields provided by numerical meteorological models (Sofiev et al., 2010).

Physical-chemical modules of SILAM include several tropospheric chemistry schemes, description of primary anthropogenic and natural aerosols and radioactive processes. The current study utilises the Carbon Bond 4 (CB4) (Gery et al., 1989) chemical mechanism and the removal processes are described via dry and wet deposition. Dry deposition is described according to Slinn and Slinn (1980) and Sofiev et al. (2008). Wet deposition distinguishes between sub- and incloud scavenging by both rain and snow (Sofiev et al., 2006; Horn et al., 1987; Smith and Clark, 1989; Jylhä, 1991).

For the current study, emission of two sets of natural compounds is embedded into the dynamic simulations: biogenic VOC and sea salt (Sofiev et al., 2011). The biogenic VOC computations follow the NATAIR model approach (Poupkou et al., 2010) and the basic land-use features from the USGS classification, providing isoprene and mono-terpene emissions (currently, only isoprene emission is used in the CB4 mechanism). Evaluation of the SILAM model for previous simulations of surface ozone can be found in Solazzo et al. (2012).

\subsubsection{The MATCH model}

The regional offline Eulerian CTM MATCH is developed at the Swedish Meteorological and Hydrological Institute. The model structure, boundary layer parameterization, advection scheme and numerical treatment are given in Robertson et al. (1999).

The chemical scheme in MATCH, based on Simpson et al. (1993), with extensions described in Andersson et al. (2007), considers about 70 species and 130 chemical reactions including the relevant photochemistry for ozone. The dry deposition of gases and aerosols is calculated using a resistance approach depending on land surface type. The wet scavenging is assumed to be proportional to the precipitation intensity for most gaseous and aerosol components. For $\mathrm{O}_{3}$, hydrogen peroxide $\left(\mathrm{H}_{2} \mathrm{O}_{2}\right)$ and $\mathrm{SO}_{2}$ in-cloud scavenging is calculated assuming Henry's law equilibrium; sub-cloud scavenging is neglected for these species. Important model 
Table 2. Model characteristics.

\begin{tabular}{|c|c|c|c|c|c|c|}
\hline Model & Type & Horizontal grid & $\begin{array}{l}\text { Lowest model } \\
\text { layer }(\mathrm{m})\end{array}$ & $\begin{array}{l}\text { Model } \\
\text { top }(\mathrm{km})\end{array}$ & $\begin{array}{l}\# \\
\text { levels }\end{array}$ & $\begin{array}{l}\text { Meteorological } \\
\text { input data }\end{array}$ \\
\hline DEHM & Eulerian/Offline & $150 \mathrm{~km} \times 150 \mathrm{~km}$ polar stereographic & 60 & 16 & 20 & ECHAM5 A1B-r3 (global data) \\
\hline EnvClimA & Eulerian/Online & $50 \mathrm{~km} \times 50 \mathrm{~km}$ Lambert & 50 & 20 & 18 & ECHAM5 A1B-r3 (global data) \\
\hline EMEP & Eulerian/Offline & $0.44^{\circ} \times 0.44^{\circ}$ rotated latitude longitude & 90 & 16 & 20 & ECHAM5 A1B-r3 RCA3 \\
\hline SILAM & Eulerian/Offline & $0.44^{\circ} \times 0.44^{\circ}$ rotated latitude longitude & 25 & 10 & 10 & ECHAM5 A1B-r3 RCA3 \\
\hline MATCH & Eulerian/Offline & $0.44^{\circ} \times 0.44^{\circ}$ rotated latitude longitude & 60 & 5.5 & 15 & ECHAM5 A1B-r3 RCA3 \\
\hline
\end{tabular}

parameters, such as dry deposition velocities and scavenging coefficients are tabulated in Andersson et al. (2007).

Emission of biogenic isoprene is calculated online in MATCH following Simpson et al. (1995).

Evaluation of the MATCH model for previous simulations of surface ozone can be found in Langner et al. (2005), Andersson et al. (2007) and Andersson and Engardt (2010).

\subsection{Model setup}

Table 2 summarizes information on the setup of the different models. Although all models have used the same basic climate projection and the same anthropogenic ozone precursor emissions, three of the models, MATCH, EMEP and SILAM have been run with identical meteorological input data downscaled with RCA3 using the same horizontal grid; the same 3-D chemical boundary conditions generated by the DEHM model and the same anthropogenic emission data from RCP4.5. However, the vertical discretization was left free to each model. It should be noted that the meteorological input available from the RCA3 downscaling of ECHMA5 A1B-r3 lacks some fields normally used in the standard application of the different models, in particular 3-D precipitation, and also has a horizontal grid which is different. Due to computation and storage constraints ozone output was stored every six hours from EnvClimA, while the other models stored ozone output at one hour time resolution.

\section{Results}

\subsection{Comparison to observations}

In Table 3 we compare the performance of the four CTMs and the CCM (EnvClimA) at EMEP stations throughout Europe. The locations of the stations and the observed values are plotted in Figs. 7 and 8. The observations are averaged over the period 1997-2003 to be centred on the year of emissions (2000) while the model data are taken from simulations forced by climate model data covering the reference period, 2000-2009. We have evaluated the models' capabilities to reproduce diurnal average and average of daily maximum $\mathrm{O}_{3}$ concentration over the full year and during summer time (April-September). Note also that the results for EnvClimA are based on instantaneous data every six hours while the re- sults from all other models are based on hourly averages and that anthropogenic emissions in EnvClimA lack seasonal and diurnal variations. While the observations are typically taken at $\sim 3 \mathrm{~m}$ height, the model data are from the lowest model layers (typically $25 \mathrm{~m}$ to $90 \mathrm{~m}$ thick, see Table 2) - making the model results not strictly comparable to each other. The DEHM model also features larger horizontal grid squares $\left(150 \times 150 \mathrm{~km}^{2}\right)$ than the other models - which all operate on a horizontal grid of ca. $50 \times 50 \mathrm{~km}^{2}$.

For yearly averages EnvClimA has a negative bias for both mean and daily maximum $\mathrm{O}_{3}$ exceeding $20 \%$. This may be due to underestimation in the winter temperature in the downscaling by EnvClimA (not shown) over northeast Europe. For the summer period the bias is reduced to $-6.7 \%$ for the mean which is similar to the DEHM model $(-5.5 \%)$ model. Both DEHM and EnvClimA also underestimate the daily maximum concentration in summer considerably ( -19.2 and $-17.1 \%$ respectively). The negative bias in EnvClimA is also partly related to the use of six-hourly $\mathrm{O}_{3}$ output data, the lack of diurnal cycles in emissions and the omission of biogenic isoprene emissions. SILAM and EMEP overestimate the diurnal average concentration but this overestimation would be reduced if concentrations had been extrapolated to three meter level. The MATCH model has a slight positive bias for mean concentrations and a negative bias for mean of daily maximum. For all models the bias changes in the negative direction when going from mean to daily maximum values, which results in a general underestimation of the highest values in all models.

The spatial correlation, in all models, is rather poor (0.4$0.6)$ for the diurnal average annual mean concentration, but for the average of daily maximum $\mathrm{O}_{3}$ concentration all models display correlation coefficients larger than 0.8 during summer. The gradients in ozone concentrations across Europe are larger during summer due to a stronger photochemical activity resulting in higher concentrations in continental and southern Europe. The models seem to capture a substantial part of these gradients and the spatial correlation therefore improves for the summer season. The EnvClimA model features similarly high correlation as SILAM but has the largest RMSE of the high resolution models, while SILAM has among the lowest.

Figure 5 shows the seasonal cycle of simulated monthlymean (24h average) $\mathrm{O}_{3}$ concentrations at EMEP sites in 
Table 3. Statistical evaluation of model results for surface $\mathrm{O}_{3}{ }^{*}$.

\begin{tabular}{|c|c|c|c|c|}
\hline & Annual mean & AMJJAS mean & Annual daily max & AMJJAS daily $\max$ \\
\hline \multicolumn{5}{|l|}{ Mean ppb(v) } \\
\hline Observations & 30.8 & 36.4 & 41.6 & 49.6 \\
\hline DEHM & 28.9 & 34.2 & 34.5 & 40.1 \\
\hline EnvClimA & 24.6 & 34.0 & 30.3 & 41.1 \\
\hline EMEP & 36.1 & 42.4 & 42.4 & 49.0 \\
\hline SILAM & 34.8 & 42.3 & 40.4 & 48.0 \\
\hline МАTCH & 31.4 & 37.3 & 39.9 & 45.4 \\
\hline \multicolumn{5}{|l|}{ Bias $\%$} \\
\hline DEHM & -2.9 & -5.5 & -16.9 & -19.2 \\
\hline EnvClimA & -20.2 & -6.7 & -27.2 & -17.1 \\
\hline EMEP & 17.3 & 16.4 & 2.0 & -1.1 \\
\hline SILAM & 13.1 & 16.1 & -3.0 & -3.2 \\
\hline MATCH & 2.1 & 2.3 & -3.9 & -8.4 \\
\hline \multicolumn{5}{|c|}{ Spatial correlation } \\
\hline DEHM & 0.53 & 0.64 & 0.67 & 0.84 \\
\hline EnvClimA & 0.60 & 0.78 & 0.79 & 0.90 \\
\hline EMEP & 0.43 & 0.69 & 0.67 & 0.85 \\
\hline SILAM & 0.60 & 0.75 & 0.83 & 0.91 \\
\hline MATCH & 0.56 & 0.63 & 0.68 & 0.82 \\
\hline \multicolumn{5}{|l|}{ RMSE ppb(v) } \\
\hline DEHM & 3.9 & 5.7 & 7.7 & 10.5 \\
\hline EnvClimA & 7.2 & 4.9 & 11.6 & 9.1 \\
\hline EMEP & 6.8 & 7.8 & 3.3 & 4.2 \\
\hline SILAM & 5.4 & 7.5 & 2.8 & 4.0 \\
\hline МАTCH & 3.8 & 5.4 & 3.5 & 6.1 \\
\hline \# stations & 59 & 63 & 59 & 61 \\
\hline \multicolumn{5}{|c|}{ Temporal correlation for monthly average variations in each quadrant of the simulation domain } \\
\hline & NW & $\mathrm{NE}$ & SW & SE \\
\hline DEHM & 0.95 & 0.96 & 0.97 & 0.97 \\
\hline EnvClimA & 0.85 & 0.71 & 0.93 & 0.93 \\
\hline EMEP & 0.96 & 0.92 & 0.95 & 0.94 \\
\hline SILAM & 0.95 & 0.86 & 0.97 & 0.96 \\
\hline МАTCH & 0.95 & 0.97 & 0.97 & 0.98 \\
\hline
\end{tabular}

* Model results are for lowest model level. Observations are for the period 1997-2003. Sites at an elevation deviating more than $250 \mathrm{~m}$ from the model height or with a data capture less than $90 \%$ and five years were excluded from the evaluation. Results for EnvClimA are based on instantaneous 6-hourly data.

Europe averaged over the reference period (2000-2009) compared to observations averaged over the period 19972003. The average seasonal variation of the stations in each quadrant of the simulation domain is shown. Station locations are shown in Fig. 6. Temporal correlations for the different models and areas are given in Table 3. Most models reproduce the broad summer maximum in the south and all models have temporal correlations that are higher than 0.93 for SW and SE stations. EnvClimA has lower correlation than the other models for NW and NE. This is connected to the lack of a spring peak in ozone in EnvClimA. The positive bias in average ozone in EMEP and SILAM (cf. Table 3) is most pronounced in the north-western and north-eastern part of the domain. SILAM overestimates average $\mathrm{O}_{3}$ during summer and autumn throughout the domain. EMEP is the only model to exhibit a local minimum in June-July. This is also seen in the observations for the different quadrants. This minimum in the EMEP results is rather the gap between two maxima - that associated with the springtime peak of ozone seen across much of the continent (as discussed by Monks, 2000) and the later summertime peak arising from increased Europe-scale photochemistry. This point was also noted in Colette et al. (2011). 


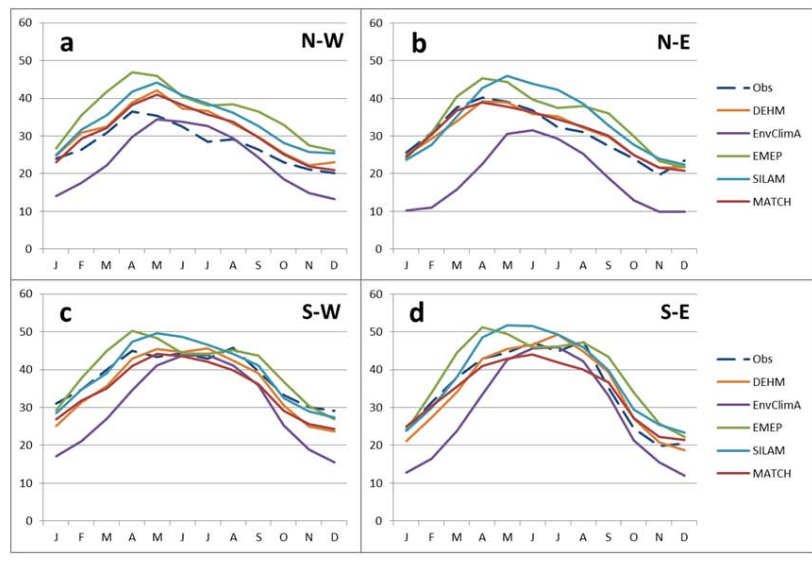

Fig. 5. Model simulated and observed seasonal cycle of monthly average surface $\mathrm{O}_{3}$ concentrations for each quadrant of the simulation domain. Observations are averages for the period 1997-2003 and for stations indicated in Figure 6. The number of stations in each quadrant is (a) 24, (b) 26, (c) 14 and (d) 17. Model results are for the reference period, 2000-2009, using meteorology from each CTM's driving climate model (ECHAM5 A1B-r3, ECHAM5 A1Br3 and $3 \times$ ECHAM5 A1B-r3-RCA3), and are from lowest model layer, ca. 25-45 $\mathrm{m}$ height. Units ppb(v).

EnvClimA generally underestimates ozone concentrations, especially during winter and in north-east Europe, connected to the bias in winter temperature discussed earlier. MATCH and DEHM feature similar temporal and spatial variations, with overestimations of average $\mathrm{O}_{3}$ concentrations during summer and autumn in the north-western part of the domain and underestimations in the south-western part of the domain during all seasons except summer.

\subsection{Current situation}

Figure 7 shows summer time (April-September) diurnal average $\mathrm{O}_{3}$ concentration in the lowest model layer, as simulated by the five models. The general features, with higher $\mathrm{O}_{3}$ concentrations in the south, especially over the Mediterranean Sea, are evident in all models. MATCH and EMEP have more pronounced differences between $\mathrm{O}_{3}$ over land and sea than the other models. SILAM calculates the highest ozone concentrations over south European land masses, while MATCH features the lowest concentrations in southern Europe, including the Mediterranean Sea. EnvClimA features the lowest concentration in north-east Europe.

Figure 8 shows modelled summer time averages of daily maximum $\mathrm{O}_{3}$ concentrations across Europe. In the evaluation above, both SILAM and EMEP performed very well for this measure, with absolute biases of $\sim 3 \%$ and spatial correlations of 0.85 or higher. In Fig. 8 SILAM features higher values in the northern and eastern part of the domain and over Italy, while EMEP displays higher values over to the west and over water. EnvClimA displays a zonal behaviour of

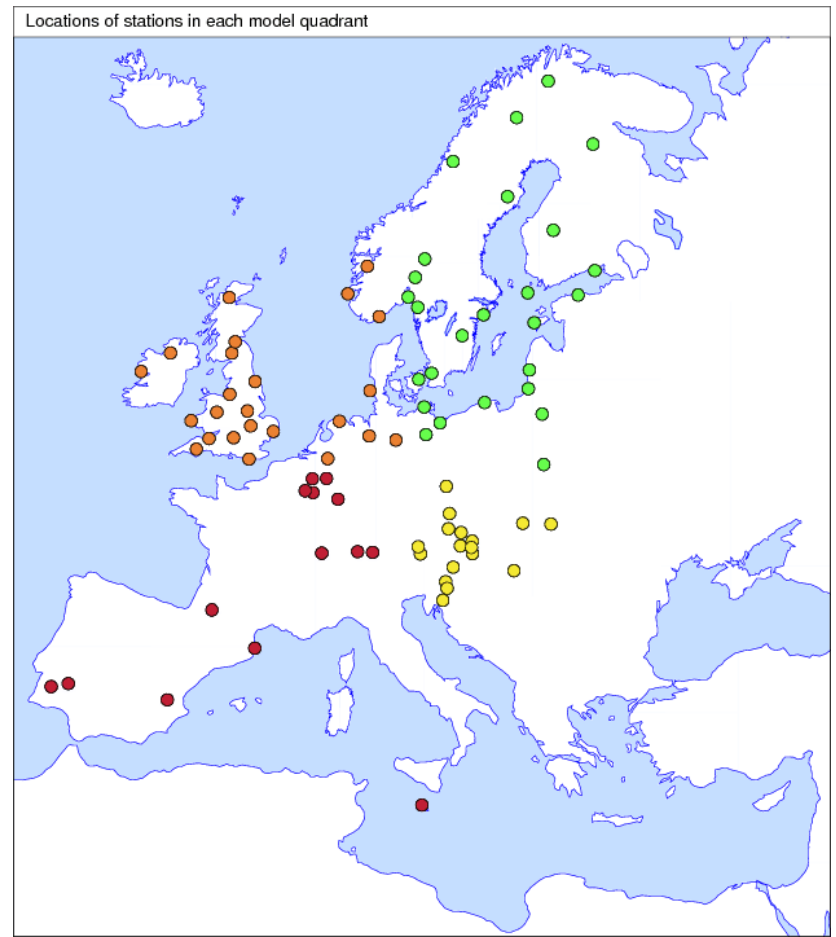

Fig. 6. Colour coded locations of the stations in each model quadrant used to derive the seasonal variation plots in Fig. 5 in the paper.

average daily maximum concentrations while DEHM, as expected, shows the smoothest variation with high daily maximum concentrations over Italy and adjacent areas of the Mediterranean Sea. MATCH, on the other hand, shows a patchy picture, indicating shorter residence time of high $\mathrm{O}_{3}$ and/or strong effects of local processes which are not present to the same extent in the other models.

\subsection{Climatically induced changes in ozone concentrations}

Figure 9 shows the modelled change in average summer time $\mathrm{O}_{3}$ concentration from the reference period to the future period. Only results that are statistically significant at the $95 \%$ level with regard to interannual variations are plotted. Note that the anthropogenic emissions of ozone precursors were identical during the two periods to isolate the change in surface $\mathrm{O}_{3}$ due to climate change. Most models simulate increase of surface $\mathrm{O}_{3}$ in southern Europe and decreasing $\mathrm{O}_{3}$ concentrations in northern Europe. EnvClimA however, shows very small increases in surface ozone indicating that the online coupling of gas phase components has a small effect and that inclusion of changes in isoprene emissions should have a larger effect. MATCH displays increasing average $\mathrm{O}_{3}$ concentrations also in the North Atlantic east of Iceland. This area coincides with a co-located region of particularly pronounced temperature increase over this period (cf. Fig. 2). The reason for the $\mathrm{O}_{3}$ increase is related to 

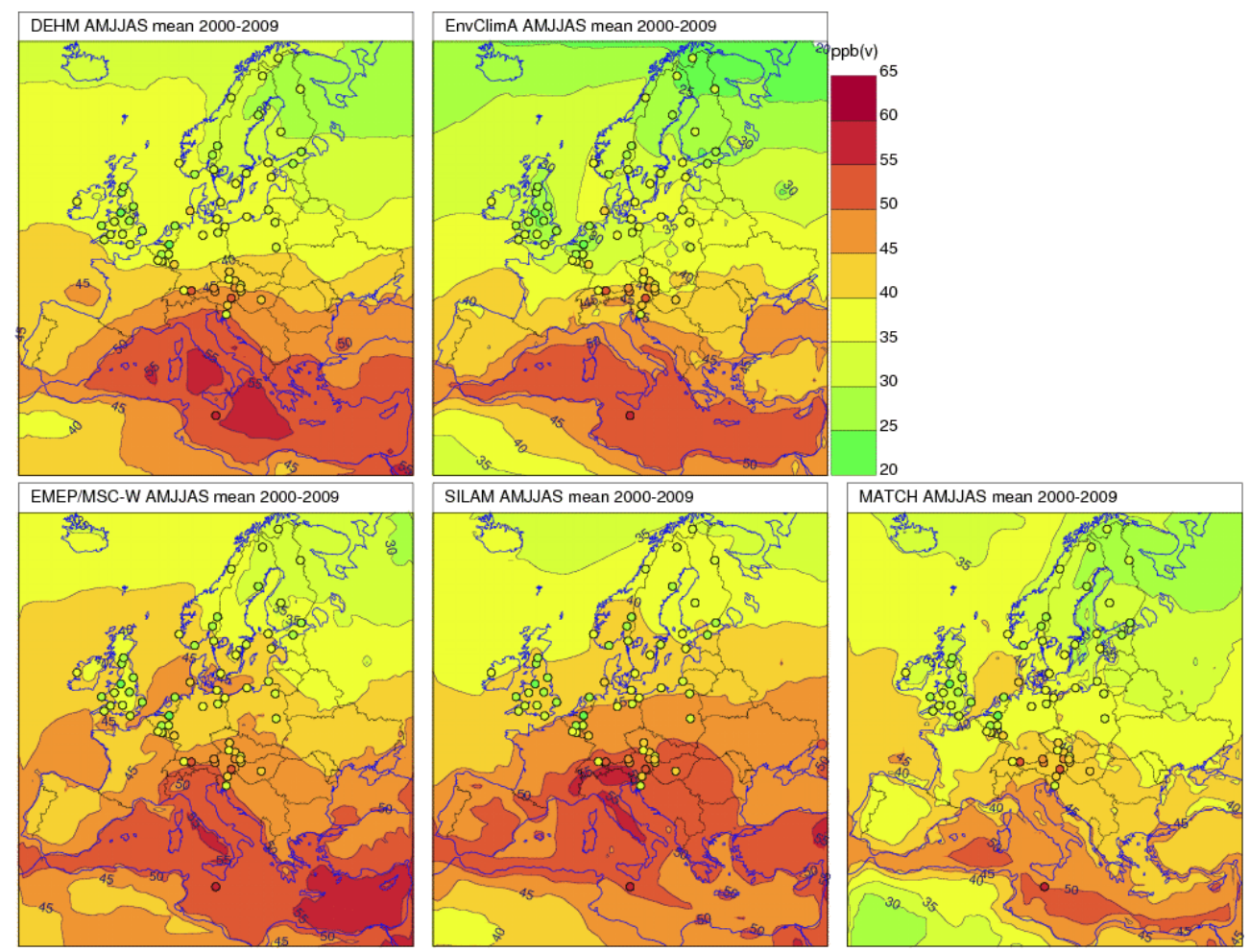

Fig. 7. Simulated April-September average $\mathrm{O}_{3}$ concentration at the lowest model level for the period 2000-2009. Coloured circles indicate the observed values at the stations used in the model evaluation given in Table 3. Units $\mathrm{ppb}(\mathrm{v})$.

both the locally increasing temperatures - affecting the $\mathrm{O}_{3}$ chemistry - and to a shift in the average wind direction in the area from south-west to a more southerly direction (not shown) which results in a shift of the area influenced by reduced surface $\mathrm{O}_{3}$ concentrations due to dry deposition over Iceland. MATCH is the only model that features decreasing $\mathrm{O}_{3}$ concentrations over the Mediterranean Sea in a future climate. This could be caused by a relatively higher sensitivity in MATCH of $\mathrm{O}_{3}$ losses through photolysis and reaction with water vapour. The reasons for reduced concentrations in northern Europe have not been considered in detail, but both cloudiness and precipitation increase in northern Europe in the climate projection and time periods used here, leading to increased scavenging of ozone precursors and less solar radiation for driving the photochemistry in these areas. Maxima in increased relative humidity in the Mediterranean are colocated with the decrease in ozone simulated with MATCH giving some support for the hypothesis that reaction with water vapour could be part of the explanation.

The hemispheric model DEHM shows the largest climate induced increase of surface $\mathrm{O}_{3}$ concentrations of all models. This is partly due to a larger temperature increase in the global model data used to drive the DEHM model and the resolution effect on isoprene emissions discussed above. MATCH displays sharper gradients in the changes in southern Europe between land and sea. Apart from En-
vClimA the SILAM model shows the least sensitivity of surface $\mathrm{O}_{3}$ concentration to climate change. In the SILAM model the increase in average summertime $\mathrm{O}_{3}$ concentration barely reaches $1 \mathrm{ppb}(\mathrm{v})$ in a few grid-cells. In MATCH part of Spain, Italy and the Balkans get $\mathrm{O}_{3}$ increases larger than $1 \mathrm{ppb}(\mathrm{v})$ while in DEHM most of south-eastern Europe gets summer mean $\mathrm{O}_{3}$ increases larger than $2 \mathrm{ppb}(\mathrm{v})$. MATCH and EMEP also calculate significant decreases of average $\mathrm{O}_{3}$ in the northern part of the domain (i.e. north Norway, Sweden, Finland and north-western Russia). Figure 9 also includes the average results for the MATCH, EMEP and SILAM models. Since these models used identical input data this panel shows the average sensitivity to climate change for these models. The ensemble mean change of mean $\mathrm{O}_{3}$ for these three models exceed $1 \mathrm{ppb}(\mathrm{v})$ in parts of the land area in southern Europe.

The change in summer average daily maximum $\mathrm{O}_{3}$ concentration is shown in Fig. 10. While the absolute values of the changes are larger than in the case of the average summer time concentrations, the spatial features are similar. All models display a patchier pattern than in the case of the average concentrations. MATCH is also still the only model featuring decreasing daily maximum $\mathrm{O}_{3}$ concentrations over the Mediterranean Sea in a future climate. The ensemble mean change of summer daily maximum $\mathrm{O}_{3}$ for the EMEP, SILAM 

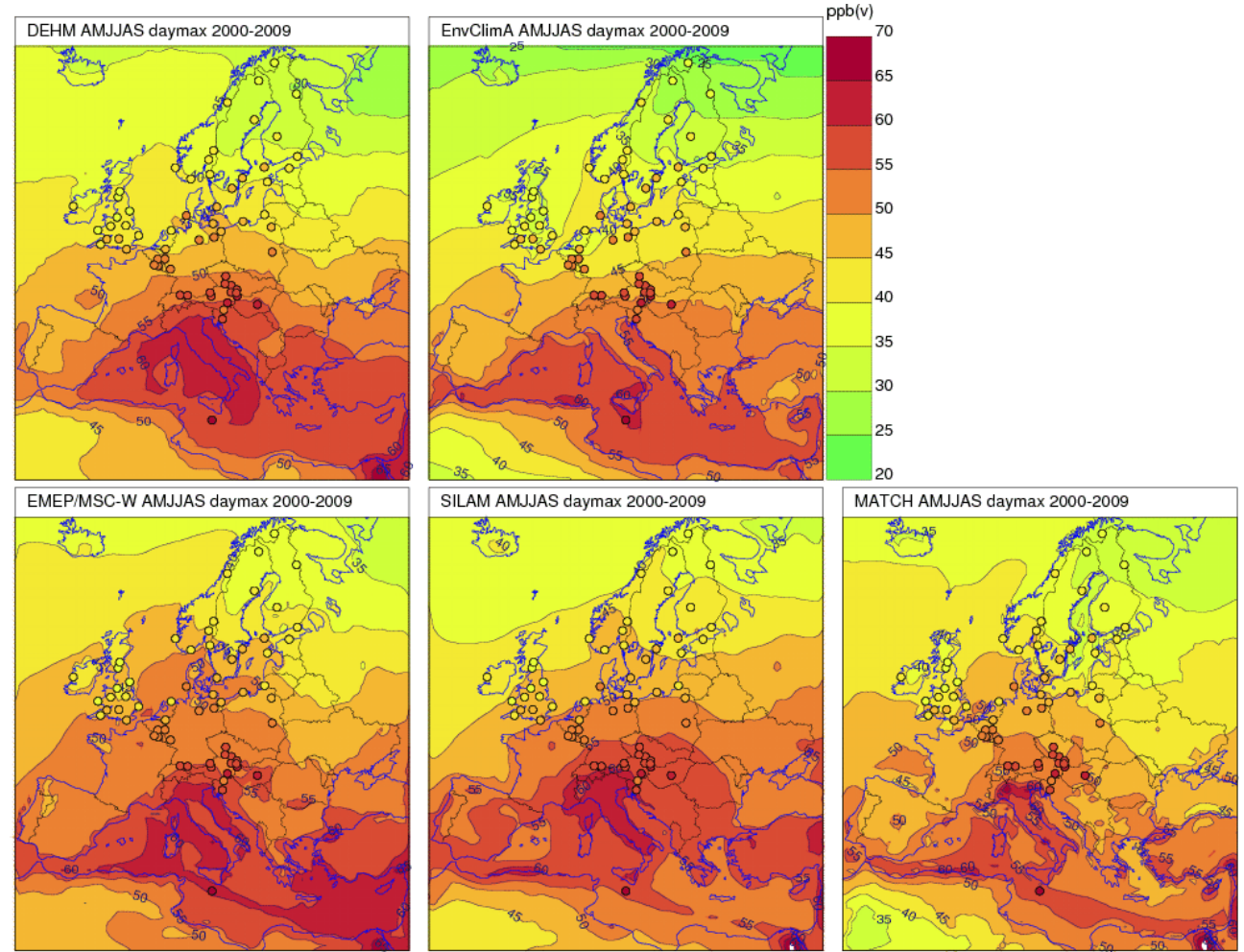

Fig. 8. Simulated April-September average daily maximum $\mathrm{O}_{3}$ concentration at the lowest model level for the reference period, 2000-2009. Coloured circles indicate the observed values at the stations used in model evaluation given in Table 3. Units $\mathrm{ppb}(\mathrm{v})$.
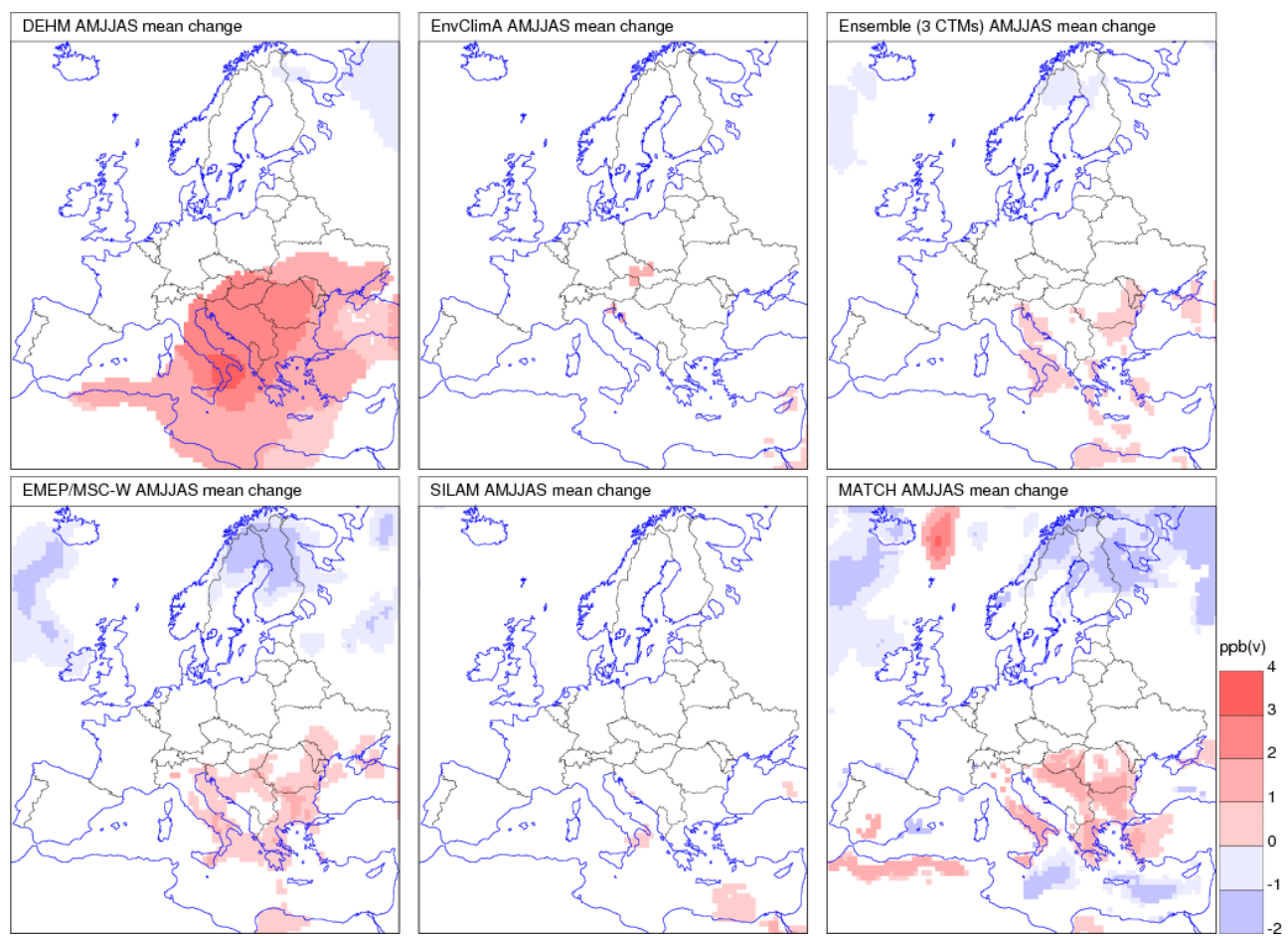

Fig. 9. Simulated April-September change 2000-2009 to 2040-2049 in average $\mathrm{O}_{3}$ concentration at the first model level. Only changes that are statistically significant at the $95 \%$ level are plotted. Units $\mathrm{ppb}(\mathrm{v})$. 

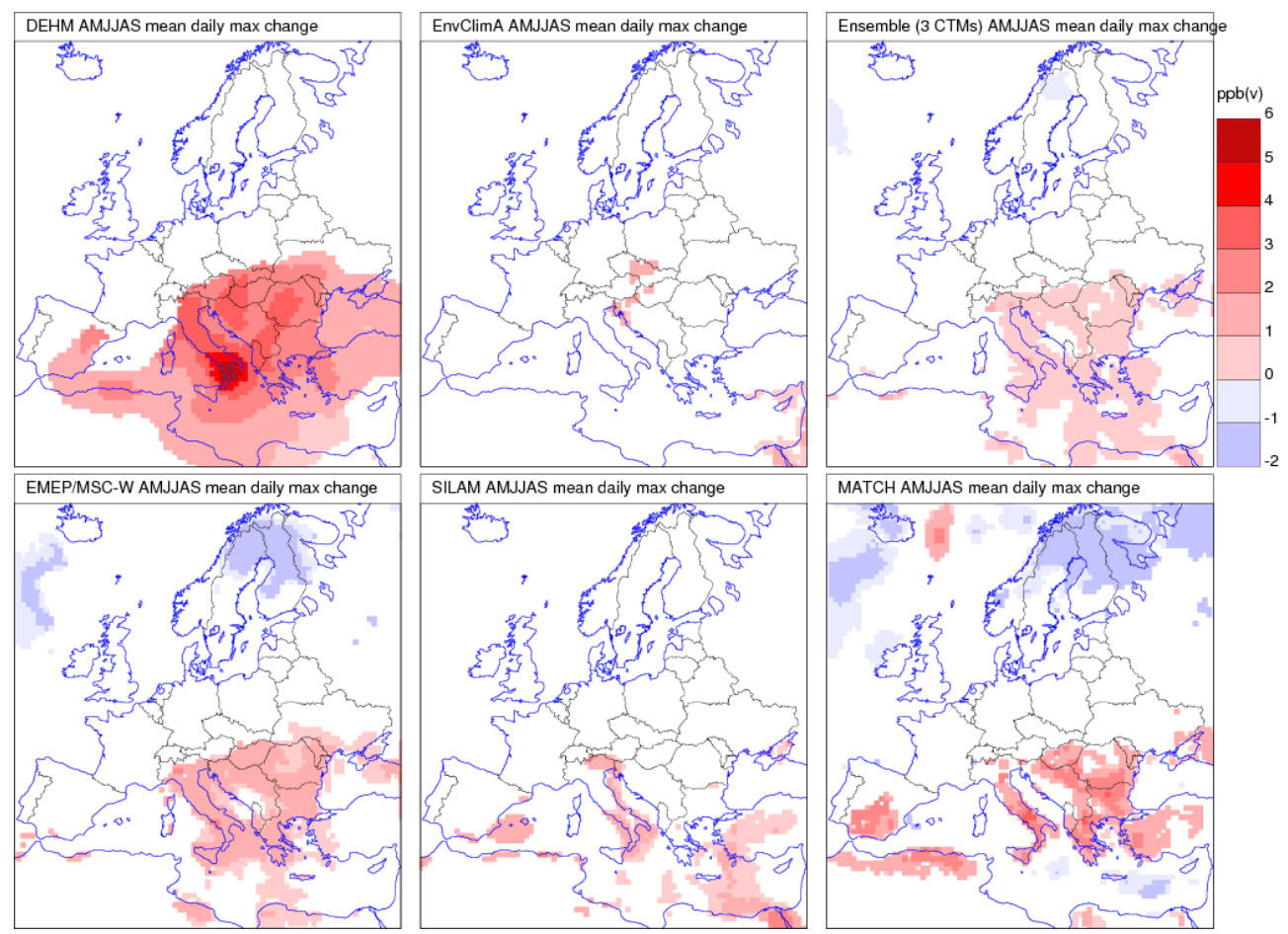

Fig. 10. Simulated April-September change 2000-2009 to 2040-2049 in average daily maximum $\mathrm{O}_{3}$ concentration at the first model level. Only changes that are statistically significant at the $95 \%$ level are plotted. Units $\mathrm{ppb}(\mathrm{v})$.

and MATCH models exceed $1 \mathrm{ppb}(\mathrm{v})$ in parts of the land area in southern Europe.

Figure 11 shows the change in April-September 95percentile of hourly $\mathrm{O}_{3}$ concentrations between the reference period and the future period. DEHM again stands out with the largest increase of all models while SILAM features the lowest increase. Although MATCH is the only model simulating increase in the 95-percentile of $\mathrm{O}_{3}$ of more than $2 \mathrm{ppb}(\mathrm{v})$ in southern Spain, all models agree that the increase in 95-percentile is more extended than the change in daily maximum concentrations. Apart from MATCH, which still simulates substantial $\mathrm{O}_{3}$ decreases in northern Europe all models simulate a more widespread increase in the higher percentiles of hourly $\mathrm{O}_{3}$ concentrations over Europe in a future climate, indicating that climate impacts on $\mathrm{O}_{3}$ could be especially important in connection with extreme summer events such as experienced in summer 2003. The ensemble mean change of April-September 95-percentile of hourly $\mathrm{O}_{3}$ concentrations for the EMEP, SILAM and MATCH models is just below $2 \mathrm{ppb}(\mathrm{v})$ in parts of the land area in southern Europe.

\section{Discussion}

In Table 4 we list the maximum positive significant changes for mean, daily max and 95-percentile of summer ozone for the different models. It is clear that changes in isoprene emis- sions are important for explaining part of the sensitivity of the models. EnvClimA which excludes biogenic isoprene emissions has the lowest sensitivity while DEHM which has the largest absolute change in isoprene emissions has the strongest sensitivity for all ozone measures studied. Other factors than isoprene emission are important though. Although SILAM has the second largest change in isoprene emissions SILAM shows the lowest sensitivity after EnvClimA while MATCH which has the smallest increase in biogenic isoprene emissions has the second largest sensitivity to climate change. In the case of MATCH additional sensitivity to climate changes is related to the inclusion of a dependence on soil moisture for the dry deposition of ozone as shown by Andersson and Engardt (2010). The range of sensitivity for the different measures between the models is about a factor of two. The simulated sensitivity of surface $\mathrm{O}_{3}$ to changes in climate can be compared to results from earlier studies e.g. Meleux et al. (2007); Forkel and Knoche (2006, 2007); Hedegaard et al. (2008); Andersson and Engardt (2010). They simulate larger changes than shown here, but in all these cases the climate projections used were based on the SRES A2 scenario which gives a stronger climate change signal. The time span over which the changes were evaluated were also up to twice as long as the 40-yr period used in this study. Katragkou et al. (2011) found changes of similar magnitude as given here in summer mean ozone between the periods 1990-2000 and 2041-2050 using the A1B 

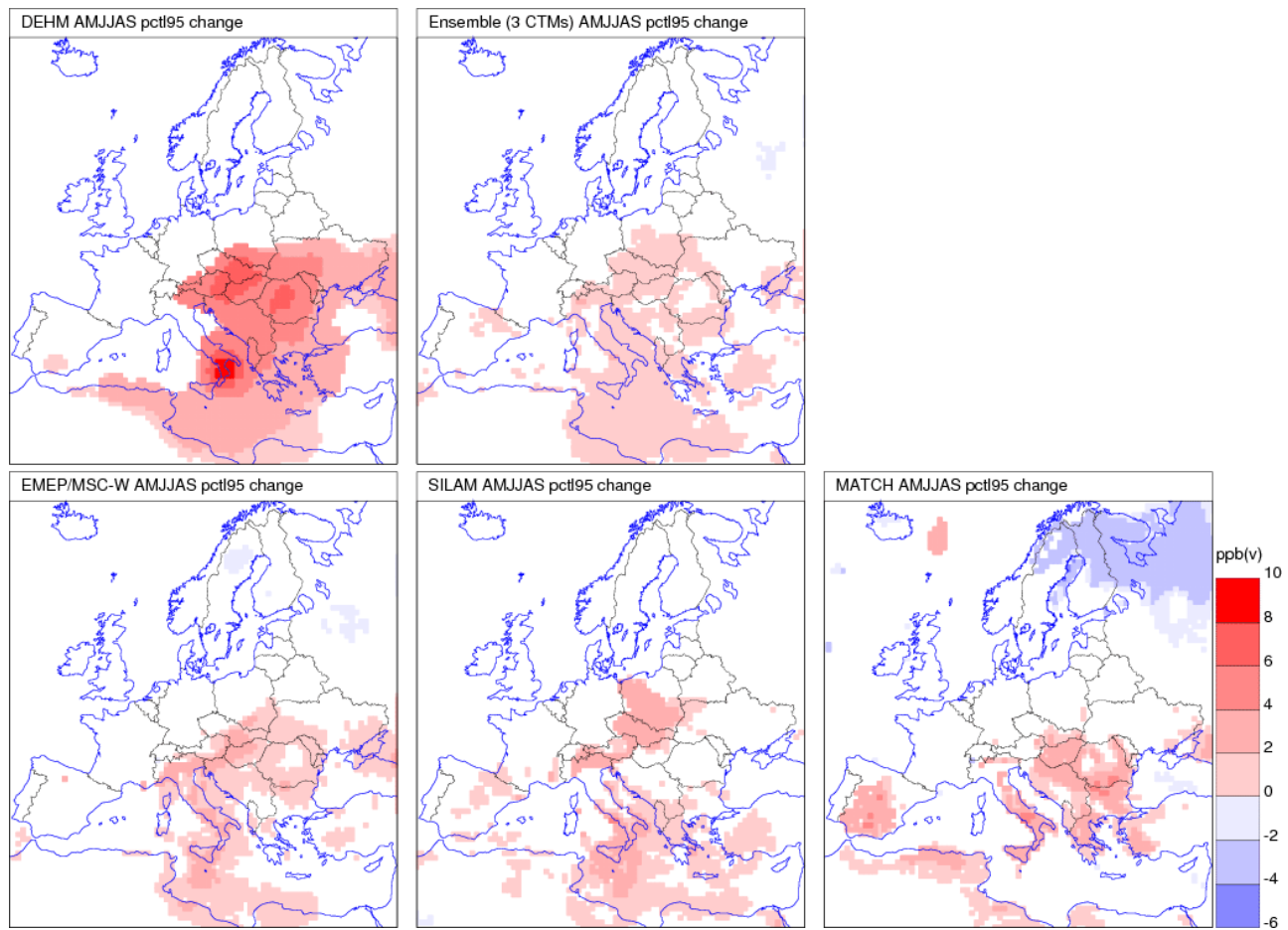

Fig. 11. Simulated April-September change 2000-2009 to 2040-2049 in 95-percentile $\mathrm{O}_{3}$ concentration at the first model level. Only changes that are statistically significant at the $95 \%$ level are plotted. Units $\mathrm{ppb}(\mathrm{v})$.

Table 4. Maximum positive changes in mean, daily max and 95percentile of summer surface $\mathrm{O}_{3}$.

\begin{tabular}{lccc}
\hline & Mean & Daily max & 95-percentile \\
\hline DEHM & 3.6 & 5.9 & 9.8 \\
EnvClimA & 1.3 & 1.7 & - \\
EMEP & 1.7 & 2.2 & 4.1 \\
SILAM & 1.2 & 3.0 & 3.0 \\
MATCH & 3.0 & 3.4 & 5.4 \\
Ensemble & 0.9 & 1.3 & 2.0 \\
\hline
\end{tabular}

climate scenario from the ECHAM5 model. Their simulated surface ozone mostly decreases by $0.5-1 \mathrm{ppb}(\mathrm{v})$ over the European domain and slightly increases over south-eastern $\mathrm{Eu}-$ rope. The changes are found to be significant only over northern and south-eastern Europe.

The change in surface ozone caused by climate change should also be related to changes due to anticipated changes in European precursor emissions. In an earlier study using the EMEP model driven by climate data from HadCM3 and SRES A1B, downscaled by HIRHAM to $25 \times 25 \mathrm{~km}^{2}$ resolution, Nyíri et al. (2010) found that the increase in daily maximum $\mathrm{O}_{3}$ from the 2000's to the 2050's due to climate change is overridden by changes in European $\mathrm{O}_{3}$ precursor emissions.
Engardt et al. (2009) assessed changes in surface $\mathrm{O}_{3}$ and AOT40 from 2004 to 2020. They concluded that emission reductions would have a large beneficial impact on near surface $\mathrm{O}_{3}$ across Europe. Changes in AOT40 due to likely emission reductions were always larger than changes imposed by climate change. In the northern part of Europe and along the Atlantic coast, changes in AOT40 following increased hemispheric $\mathrm{O}_{3}$ concentrations and climate change almost counterbalanced the decrease in AOT40 due to pan-European emission reductions. Langner et al. (2012) used a suite of offline simulations with MATCH to compare the impact of climate change following regional downcsaling of ECHAM5 A1B-r3 and the HadCM3 global model by RCA3, to the anticipated effect of air pollution emission changes according to the RCP4.5 scenario from 2000 to 2050 . From their analysis it was clear that emission changes dominate over climate changes in determining future $\mathrm{O}_{3}$ concentrations over Europe during summer. A systematic underestimation of the peak ozone values in the model may, however, underestimate the detrimental increases in extreme ozone concentrations that may occur in a future, warmer and drier, climate. 


\section{Conclusions}

We have studied the impact of climate change on surface $\mathrm{O}_{3}$ over Europe using four different CTMs and one CCM and the same global projection of future climate under the SRES A1B scenario. The following conclusions can be drawn:

1. The sensitivity of the simulated surface $\mathrm{O}_{3}$ to changes in climate differ by about a factor of two among models, but the general pattern of change with an increase in southern Europe is similar across several different models for the chosen climate projection. A subset of models and the ensemble also show significant decreases in parts of northern Europe.

2. Biogenic emissions of isoprene differ substantially between the CTMs ranging from 1.6 to $8.0 \mathrm{Tg} \mathrm{yr}^{-1}$ for the current climate. Also the simulated change in total isoprene emissions between the reference period and future period varies substantially across models. Apart from the different parameterizations used in the various models, differences in horizontal model resolution and corresponding horizontal resolution in temperature fields are important factors contributing to these differences.

3. Ensemble mean changes between the periods 2000 2009 and 2040-2049 in summer (April-September) mean $\mathrm{O}_{3}$ and mean of daily maximum $\mathrm{O}_{3}$ are close to $1 \mathrm{ppb}(\mathrm{v})$ in parts of the land area in southern Europe assuming no changes in anthropogenic air pollution emissions. Corresponding changes of 95-percentiles of hourly $\mathrm{O}_{3}$ are close to $2 \mathrm{ppb}(\mathrm{v})$ in the same region. In northern Europe ensemble mean changes in mean and daily maximum show negative changes while there are no negative changes for the higher percentiles indicating that climate impacts on $\mathrm{O}_{3}$ could be especially important in connection with extreme summer events.

Acknowledgements. This study was supported by the Nordic Council of Ministers (EnsCLIM project no: KoL-10-04), the EU projects ECLAIRE (project no: 282910), MEGAPOLI (no: 212520), TRANSPHORM (no: 243406), Swedish Environmental Protection Agency through the research programme CLEO Climate Change and Environmental Objectives as well as EMEP under UNECE.

Edited by: A. S. H. Prevot

\section{References}

Alapaty, K., Mathur, R., Pleim, J., Hogrefe, Ch., Rao, S. T., Ramaswamy, V., Galmarini, S., Schaap, M., Vautard, R., Makar, P., Baklanov, A., Kallos, G., Vogel, B., and Sokhi, R.: New Directions: Understanding Interactions of Air Quality and Climate Change at Regional Scales, Atmos. Environ., 49, 419-421, doi:10.1016/j.atmosenv.2011.12.016, 2011.
AMAP: AMAP Assessment 2011: Mercury in the Arctic. Arctic Monitoring and Assessment Programme (AMAP), Oslo, Norway. xiv+193 pp., 2011.

Andersson, C. and Engardt, M.: European ozone in a future climate - The importance of changes in dry deposition and isoprene emissions, J. Geophys. Res., 115, D02303, doi:10.1029/2008JD011690, 2010.

Andersson, C., Langner, J., and Bergström, R.: Interannual variation and trends in air pollution over Europe due to climate variability during 1958-2001 simulated with a regional CTM coupled to the ERA40 reanalysis, Tellus B, 59, 77-98, 2007.

Andersson-Sköld, Y. and Simpson, D.: Comparison of the chemical schemes of the EMEP MSC-W and IVL photochemical trajectory models, Atmos. Environ., 33, 1111-1129, doi:10.1016/s1352-2310(98)00296-9, 1999.

Arneth, A., Miller, P. A., Scholze, M., Hickler, T., Schurgers, G., Smith, B., and Prentice, I. C.: $\mathrm{CO}_{2}$ inhibition of global terrestrial isoprene emissions: Potential implications for atmospheric chemistry, Geophys. Res. Lett., 34, L18813, doi:10.1029/2007GL030615, 2007.

Arneth, A., Schurgers, G., Lathiere, J., Duhl, T., Beerling, D. J., Hewitt, C. N., Martin, M., and Guenther, A.: Global terrestrial isoprene emission models: sensitivity to variability in climate and vegetation, Atmos. Chem. Phys., 11, 8037-8052, doi:10.5194/acp-11-8037-2011, 2011.

Ashmore, M.: Assessing the Future Global Impacts of Ozone on Vegetation, Plant Cell Enviro., 28, 949-964, 2005.

Asman, W. A. H., Sørensen, L. L., Berkowicz, R., Granby, K., Nielsen, H., Jensen, B., Runge, E., Lykkelund, C., Gryning, S. E., and Sempreviva, A. M.: Dry deposition processes, Danish Environmental Protection Agency, Marine Research, 35, Copenhagen, Denmark, 199 pp., 1994.

Barth, M. C., Sillman, S., Hudman, R., Jacobson, M. Z., Kim, C.-H., Monod, A., and Liang, J.: Summary of the cloud chemistry modeling intercomparisons: Photochemical box model simulation, J. Geophys. Res., 108, 4214, doi:10.1029/2002JD002673, 2003.

Berge, E. and Jakobsen, H. A.: A regional scale multi-layer model for the calculation of long-term transport and deposition of air pollution in Europe, Tellus B, 50, 205-223, doi:10.1034/j.16000889.1998.t01-2-00001.x, 1998.

Brandt, J., Silver, J. D., Christensen, J. H., Frohn, L. M., Geels, C., Gross, A., Hansen, A. B., Hansen, K. M., Hedegaard, G. B., Skjøth, C. A., Villadsen, H., and Zare, A.: An integrated model study for Europe and North America using the Danish Eulerian Hemispheric Model with focus on intercontinental transport of air pollution, Atmos. Environ., 53, 156-176, doi:10.1016/j.atmosenv.2012.01.011, 2012.

Christensen, J. H.: The Danish Eulerian Hemispheric Model - a Three-Dimensional Air Pollution Model Used for the Arctic, Atmos. Environ., 31, 4169-4191, 1997.

Chang, J. S., Brost, R. A., Isaksen, I. S. A., Madronich, S., Middleton, P., Stockwell, W. R., and Walcek, C. J.: A three-dimensional eulerian acid deposition model: physical concepts and formulation, J. Geophys. Res., 92, 14681-14700, 1987.

Colette, A., Granier, C., Hodnebrog, Ø., Jakobs, H., Maurizi, A., Nyiri, A., Bessagnet, B., D’Angiola, A., D'Isidoro, M., Gauss, M., Meleux, F., Memmesheimer, M., Mieville, A., Rouïl, L., Russo, F., Solberg, S., Stordal, F., and Tampieri, F.: Air quality trends in Europe over the past decade: a first multi-model assess- 
ment, Atmos. Chem. Phys., 11, 11657-11678, doi:10.5194/acp11-11657-2011, 2011.

Cuvelier, C., Thunis, P., Vautard, R., Amann, M., Bessagnet, B., Bedogni, M., Berkowicz, R., Brandt, J., Brocheton, F., Builtjes, P., Carnavale, C., Coppalle, A., Denby, B., Douros, J., Graf, A., Hellmuth, O., Hodzic, A., Honore, C., Jonson, J. E., Kerschbaumer, A., de Leeuw, F., Minguzzi, E., Moussiopoulos, N., Pertot, C., Peuch, V. H., Pirovano, G., Rouil, L., Sauter, F., Schaap, M., Stern, R., Tarrason, L., Vignati, E., Volta, M., White, L., Wind, P., and Zuber, A.: CityDelta: A model intercomparison study to explore the impact of emission reductions in European cities in 2010, Atmos. Environ., 41, 189-207, 2007.

DEFRA: Air quality and climate change: A UK perspective. DEFRA publications, available at: http://www.defra.gov.uk/ environment/airquality/aqeg, 2007.

EEA: Air pollution in Europe 1990-2000, Topic report No 4/2003, European Environment Agency, Copenhagen, 2003.

Emberson, L., Simpson, D., Tuovinen, J.-P., Ashmore, M. R., and Cambridge, H. M.: Towards a model of ozone deposition and stomatal uptake over Europe, EMEP MSC-W Note 6/2000, 2000.

Engardt, M., Bergström, R., and Andersson, C.: Climate and emission changes contributing to changes in near-surface ozone in Europe over the coming decades: Results from model studies, Ambio, 38, 452-458, 2009.

Ellingsen, K., Gauss, M., Van Dingenen, R., Dentener, F. J., Emberson, L., Fiore, A. M., Schultz, M. G., Stevenson, D. S., Ashmore, M. R., Atherton, C. S., Bergmann, D. J., Bey, I., Butler, T., Drevet, J., Eskes, H., Hauglustaine, D. A., Isaksen, I. S. A., Horowitz, L. W., Krol, M., Lamarque, J. F., Lawrence, M. G., van Noije, T., Pyle, J., Rast, S., Rodriguez, J., Savage, N., Strahan, S., Sudo, K., Szopa, S., and Wild, O.: Global ozone and air quality: a multi-model assessment of risks to human health and crops, Atmos. Chem. Phys. Discuss., 8, 2163-2223, doi:10.5194/acpd8-2163-2008, 2008.

Forkel, R. and Knoche, R.: Regional climate changes and its impacts on photooxidant concentrations in southern Germany: Simulations with a coupled regional climate-chemistry model, J. Geophys. Res., 111, D12302, doi:10.1029/2005JD006748, 2006.

Forkel, R. and Knoche, R.: Nested regional climate-chemistry simulations for central Europe, C. R. Geosci., 339, 734-746, doi:10.1016/j.crte.2007.09.018, 2007.

Frohn, L. M.: A study of long-term high-resolution air pollution modelling, Ministry of the Environment, National Environmental Research Institute, Roskilde, Denmark, 444 pp., 2004.

Frohn, L. M., Christensen, J. H., and Brandt, J.: Development and testing of numerical methods for two-way nested air pollution modelling, Phys. Chem. Earth., 27, 1487-1494, 2002a.

Frohn, L. M.: Development of a high-resolution nested air pollution model - The numerical approach, J. Comput. Phys. Part B, 179, 68-94, 2002b.

Galperin, M. V.: The Approaches to Correct Computation of Airborne Pollution Advection, in: Problems of Ecological Monitoring and Ecosystem Modelling, vol. XVII, Gidrometeoizdat, St. Petersburg, 54-68, 2000 (in Russian).

Geels, C., Brandt, J., Christensen, J., Frohn, L., and Hansen, K.: Long-Term Calculations with a Comprehensive Nested Hemispheric Air Pollution Transport Model, in: Advances in Air Pollution Modeling for Environmental Security, NATO Science Series: IV: Earth and Environmental Sciences, edited by: Faragó,
I., Georgiev, K., and Havasi, Á., Springer, Netherlands, 185-196, 2005.

Gery, M. W., Whitten, G. Z. , Killus, J. P., and Dodge, M. C.: A photochemical kinetics mechanism for urban and regional scale computer modeling, J. Geophys. Res., 94, 12925-12956, 1989.

Giorgi, F. and Meleux, F.: Modelling the regional effects of climate change on air quality, C. R. Geoscience, 339, 721-733, 2007.

Giorgi, F., Bi, X., and Qian, Y.: Direct radiative forcing and regional climatic effects of anthropogenic aerosols over East Asia: A regional coupled climate-chemistry/aerosol model study, J. Geophys. Res., 107, 4439, doi:10.1029/2001JD001066, 2002.

Guenther, A., Hewitt, C., Erickson, D., Fall, R., Geron, C., Graedel, T., Harley, P., Klinger, L., Lerdau, M., McKay, W., Pierce, T., Scholes, B., Steinbrecher, R., Tallamraju, R., Taylor, J., and Zimmerman, P.: A global-model of natural volatile organiccompound emissions, J. Geophys. Res., 100, 8873-8892, 1995.

Guenther, A., Karl, T., Harley, P., Wiedinmyer, C., Palmer, P. I., and Geron, C.: Estimates of global terrestrial isoprene emissions using MEGAN (Model of Emissions of Gases and Aerosols from Nature), Atmos. Chem. Phys., 6, 3181-3210, doi:10.5194/acp-63181-2006, 2006.

Hedegaard, G. B., Brandt, J., Christensen, J. H., Frohn, L. M., Geels, C., Hansen, K. M., and Stendel, M.: Impacts of climate change on air pollution levels in the Northern Hemisphere with special focus on Europe and the Arctic, Atmos. Chem. Phys., 8, 3337-3367, doi:10.5194/acp-8-3337-2008, 2008.

Hertel, O., Christensen, J., Runge, E. H., Asman, W. A. H., Berkowicz, R., Hovmand, M. F., and Hov, Ø.: Development and Testing of a new Variable Scale Pollution model - ACDEP, Atmos. Environ., 29, 1267-1290, 1995.

Horn, H.-G., Bonka, H., and Maqua, M.: Measured particle bound activity size-distribution, deposition velocity, and activity concentration in rainwater after the Chernobyl accident, J. Aerosol Sci., 18, 681-684, 1987.

IPCC, Climate Change 2007: The Physical Science Basis. Contribution of Working Group I to the Fourth Assessment Report of the Intergovernmental Panel on Climate Change, edited by: Solomon, S., Qin, D., Manning, M., Chen, Z., Marquis, M., Averyt, K. B., Tignor, M., and Miller, H. L., Cambridge University Press, Cambridge, United Kingdom and New York, NY, USA, 996 pp., 2007.

Isaksen, I. S. A., Granier, C., Myhre, G., Berntsen, T. K., Dalsøren, S. B., Gauss, M., Klimont, Z., Benestad, R., Bousquet, P., Collins, W., Cox, T., Eyring, V., Fowler, D., Fuzzi, S., Jöckel, P., Laj, P., Lohmann, U., Maione, M., Monks, P., Prevot, A. S. H., Raes, F., Richter, A., Rognerud, B., Schulz, M., Shindell, D., Stevenson, D. S., Storelvmo, T., Wang, W.-C., van Weele, M., Wild, M., and Wuebbles, D.: Atmospheric Composition Change: Climate-Chemistry interactions, Atmos. Environ., 43, 5138-5192, 2009.

Jacobson, M. Z., Kaufmann, Y. J., and Rudich, Y.: Examining feedbacks of aerosols to urban climate with a model that treats 3-D clouds with aerosol inclusions, J. Geophys. Res., 112, D24205, doi:10.1029/2007JD008922, 2007.

Jonson, J. E., Stohl, A., Fiore, A. M., Hess, P., Szopa, S., Wild, O., Zeng, G., Dentener, F. J., Lupu, A., Schultz, M. G., Duncan, B. N., Sudo, K., Wind, P., Schulz, M., Marmer, E., Cuvelier, C., Keating, T., Zuber, A., Valdebenito, A., Dorokhov, V., De Backer, H., Davies, J., Chen, G. H., Johnson, B., Tarasick, D. W., Stübi, 
R., Newchurch, M. J., von der Gathen, P., Steinbrecht, W., and Claude, H.: A multi-model analysis of vertical ozone profiles, Atmos. Chem. Phys., 10, 5759-5783, doi:10.5194/acp-10-57592010, 2010a.

Jonson, J. E., Valiyaveetil, S., Wind, P., Valdebenito, A., and Gauss, M.: Model validation of the global version of the EMEP Unified model, in: Development of the EMEP global modelling framework: Progress report, Joint MSC-W/MSC-E Report, EMEP/MSC-W Technical Report 1/2010, The Norwegian Meteorological Institute, Oslo, Norway, 14-31, 2010 b.

Jylhä, K.: Empirical scavenging coefficients of radioactive substances released from Chernobyl, Atmos. Environ., 25A, 263270, 1991.

Katragkou, E., Zanis, P., Kioutsioukis, I., Tegoulias, I., Melas, D., Krüger, B. C., and Coppola, E.: Future climate change impacts on summer surface ozone from regional climate-air quality simulations over Europe, J. Geophys. Res., 116, D22307, doi:10.1029/2011JD015899, 2011.

Kjellström, E., Nikulin, G., Hansson, U., Strandberg, G., and Ullerstig, A.: 21st century changes in the European climate: uncertainties derived from an ensemble of regional climate model simulations, Tellus 63A, 24-40, doi:10.1111/j.16000870.2010.00475.x, 2011.

Köble, R. and Seufert, G.: Novel Maps for Forest Tree Species in Europe, A Changing Atmosphere, 8th European Symposium on the Physico-Chemical Behaviour of Atmospheric Pollutants, Torino, Italy, 17-20 September, 2001.

Lamarque, J.-F., Bond, T. C., Eyring, V., Granier, C., Heil, A., Klimont, Z., Lee, D., Liousse, C., Mieville, A., Owen, B., Schultz, M. G., Shindell, D., Smith, S. J., Stehfest, E., Van Aardenne, J., Cooper, O. R., Kainuma, M., Mahowald, N., McConnell, J. R., Naik, V., Riahi, K., and van Vuuren, D. P.: Historical (1850-2000) gridded anthropogenic and biomass burning emissions of reactive gases and aerosols: methodology and application, Atmos. Chem. Phys., 10, 7017-7039, doi:10.5194/acp10-7017-2010, 2010.

Langner, J., Bergström, R., and Foltescu, V.: Impact of climate change on surface ozone and deposition of sulphur and nitrogen in Europe, Atmos. Environ., 39, 1129-1141, 2005.

Langner, J., Engardt, M., and Andersson, C.: European summer surface ozone 1990-2100, Atmos. Chem. Phys., 12, 10097-10105, doi:10.5194/acp-12-10097-2012, 2012.

Lathière, J., Hewitt, C. N., and Beerling, D. J.: Sensitivity of isoprene emissions from the terrestrial biosphere to 20th century changes in atmospheric $\mathrm{CO}_{2}$ concentration, climate, and land use, Global Biogeochem. Cy., 24, GB1004, doi:10.1029/2009GB003548, 2010.

Logan, J. A.: An analysis of ozonesonde data for the troposphere: Recommendations for testing 3-D models, and development of a gridded climatology for tropospheric ozone, J. Geophys. Res., 104, 16115-16149, 1999.

Madronich, S. and Flocke, S.: The role of solar radiation in atmospheric chemistry, in: Handbook of Environmental Chemistry, edited by: Boule, P., 1-26, Springer, New York, 1999.

Meleux, F., Solmon, F., and Giorgi, F.: Increase in summer European ozone amounts due to climate change, Atmos. Environ., 41, 7577-7587, doi:10.1016/j.atmosenv.2007.05.048, 2007.

Monks, P.: A review of the observations and origins of the spring ozone maximum, Atmos. Environ., 34, 3545-3561, 2000.
Nakićenović, N., Alcamo, J., Davis, G., de Vries, B., Fenhann, J., Gaffin, S., Gregory, K., Grübler, A., Yong Jung, T., Kram, T., La Rovere, E. L., Michaelis, L., Mori, S., Morita, T., Pepper, W., Pitcher, H., Price, L., Riahi, K., Roehrl, A., Rogner, H.-H., Sankovski, A., Schlesinger, M., Shukla, P., Smith, S., Swart, R., van Rooijen, S., Victor, N., and Dadi, Z.: Emission scenarios, A special report of working group III of the Intergovernmental Panel on Climate Change, Cambridge University Press, 2000.

Nyíri, Á., Gauss, M., Tsyro, S., Wind, P., and Haugen, J. E.: Future Air Quality, including Climate Change, in: Transboundary Acidification, Eutrophication and Ground Level Ozone in Europe in 2008, EMEP Report 1/2010, 2010.

Pacifico, F., Harrison, S. P., Jones, C. D., and Sitch, S.: Isoprene emissions and climate, Atmos. Environ., 43, 6121-6135, 2009.

Poupkou, A., Giannaros, T., Markakis, K., Kioutsioukis, I., Curci, G., Melas, D., and Zerefos, C.: A model for European Biogenic Volatile Organic Compound emissions, 2010: Software development and first validation, Env. Model. Software, 25, 1845-1856, 2010.

Rinne, J., Back, J., and Hakola, H.: Biogenic volatile organic compound emissions from the Eurasian taiga: current knowledge and future directions, Boreal Env. Res., 14, 807-826, 2009.

Robertson, L., Langner, J., and Engardt, M.: An Eulerian limitedarea atmospheric transport model, J. Appl. Meteor. 38, 90-210, 1999.

Roeckner, E., Brokopf, R., Esch, M., Giogietta, M., Hagemann, S., Kornblueh, L., Manzini, E., Schlese, U., and Schulzweida, U. : Sensitivity of simulated climate to horizontal and vertical resolutions in the ECHAM5 atmosphere model, J. Clim., 19, 37713791, 2006a.

Roeckner, E., Lautenschlager, M., and Esch, M.: IPCC-AR4 MPIECHAM5_T63L31 MPI-OM_GR1.5L40 20C3M run no.3: atmosphere 6 HOUR values MPImet/MaD Germany. World Data Center for Climate. doi:10.1594/WDCC/EH5-T63L31_OMGR1.5L40_20C_3_6H, 2006b.

Roeckner, E., Lautenschlager, M., and Schneider, H.: IPCCAR4 MPI-ECHAM5_T63L31 MPI-OM_GR1.5L40 SRESA1B run no.3: atmosphere 6 HOUR values MPImet/MaD Germany. World Data Center for Climate. doi:10.1594/WDCC/EH5T63L31_OM-GR1.5L40_A1B_3_6H, 2006c.

Samuelsson, P., Jones, C. G. Willén, U. Ullerstig, A. Gollvik, S. Hansson, U. Jansson, C. Kjellström, E. Nikulin, G., and Wyser, K.: The Rossby Centre Regional Climate model RCA3: Model description and performance, Tellus A, 63, 4-23, doi:10.111/j.1600-0870.2010.00478.x, 2011.

Shalaby, A., Zakey, A. S., Tawfik, A. B., Solmon, F., Giorgi, F., Stordal, F., Sillman, S., Zaveri, R. A., and Steiner, A. L.: Implementation and evaluation of online gas-phase chemistry within a regional climate model (RegCM-CHEM4), Geosci. Model Dev., 5, 741-760, doi:10.5194/gmd-5-741-2012, 2012.

Sillman, S.: A numerical solution for equations of tropospheric chemistry based on an analysis of sources and sinks of odd hydrogen, J. Geophys. Res., 96, 20735-20744, 1991.

Simpson, D., Andersson-Sköld, Y., and Jenkin, M. E.: Updating the chemical scheme for the EMEP MSC-W oxidant model: Current status, EMEP MSC-W Note 2/93, Norwegian Meteorological Institute, Oslo, 1993.

Simpson, D., Guenther, A., Hewitt, C. N., and Steinbrecher, R.: Biogenic emissions in Europe: 1. Estimates and uncertainties, 
J. Geophys. Res., 100, 22875-22890, doi:10.1029/95JD02368, 1995.

Simpson, D., Winiwarter, W., Borjesson, G., Cinderby, S., Ferreiro, A., Guenther, A., Hewitt, C. N., Janson, R., Khalil, M. A. K., Owen, S., Pierce, T. E., Puxbaum, H., Shearer, M., Skiba, U., Steinbrecher, R., Tarrason, L., and Oquist, M. G.: Inventorying emissions from nature in Europe, J. Geophys. Res., 104, 81138152, 1999.

Simpson, D., Fagerli, H., Jonson, J. E., Tsyro, S., Wind, P., and Tuovinen, J. P.: The EMEP Uni?ed Eulerian Model. Model Description, EMEP MSC-W Report 1/2003, Norwegian Meteorological Institute, Oslo, 2003a.

Simpson, D., Tuovinen, J. P., Emberson, L., and Ashmore, M. R.: Characteristics of an ozone deposition module II: Sensitivity analysis, Water Air Soil Pollut., 143, 123-137, doi:10.1023/a:1022890603066, 2003 b.

Simpson, D., Benedictow, A., Berge, H., Bergström, R., Emberson, L. D., Fagerli, H., Flechard, C. R., Hayman, G. D., Gauss, M., Jonson, J. E., Jenkin, M. E., Nyíri, A., Richter, C., Semeena, V. S., Tsyro, S., Tuovinen, J.-P., Valdebenito, Á., and Wind, P.: The EMEP MSC-W chemical transport model - technical description, Atmos. Chem. Phys., 12, 7825-7865, doi:10.5194/acp-127825-2012, 2012.

Sitch, S., Cox, P. M., Collins W. J., and Huntingford, C.: Indirect radiative forcing of climate change through ozone effects on the land-carbon sink, Nature, 448, 791-794, doi:10.1038/nature06059, 2007.

Slinn, S. and Slinn, W.: Predictions for particle deposition on natural waters, Atmos. Environ., 12, 1013-1016, 1980.

Smith, F. B. and Clark, M. J.: The transport and deposition of radioactive debris from the Chernobyl nuclear power plant accident with special emphasis on consequences to the United Kingdom, Meteorological Office Scientific Paper, N42, HMSO, London, 1989.

Sofiev, M.: Extended resistance analogy for construction of the vertical diffusion scheme for dispersion models, J. Geophys. Res., 107, 4159, doi:10.1029/2001JD001233, 2002.

Sofiev M., Siljamo P., Valkama I., Ilvonen M., and Kukkonen, J.: A dispersion modelling system SILAM and it's evaluation against ETEX data, Atmos. Environ., 40, 674-685, 2006.

Sofiev, M., Galperin, M., and Genikhovich, E.: Construction and evaluation of Eulerian dynamic core for the air quality and emergency modelling system SILAM, NATO Science for peace and security Series C: Environmental Security, Air pollution modelling and its application, XIX, edited by: Borrego, C. and Miranda, A. I., Springer, 699-701, 2008.

Sofiev, M., Genikhovich, E., Keronen, P., and Vesala, T.: Diagnosing the surface layer parameters for dispersion models within the meteorological-to-dispersion modelling interface, J. Appl. Meteorol. Climatology, 49, 221-233, doi:10.1175/2009JAMC2210.1, 2010.

Sofiev, M., Soares, J., Prank, M., de Leeuw, G., and Kukkonen, J.: A regional-to-global model of emission and transport of sea salt particles in the atmosphere, J. Geophys. Res., 116, D21302, doi:10.1029/2010JD014713, 2011.

Solazzo, E., Bianconi, R., Vautard, R., Appel, K. W., Moran, M. D., Hogrefe, C., Bessagnet, B., Brandt, J., Christensen, J. H., Chemel, C., Coll, I., van der Gon, H. D., Ferreira, J., Forkel, R., Francis, X. V., Grell, G., Grossi, P., Hansen, A. B., Jerice- vic, A., Kraljevic, L., Miranda, A. I., Nopmongcol, U., Pirovano, G., Prank, M., Riccio, A., Sartelet, K. N., Schaap, M., Silver, J. D,. Sokhi, R. S, Vira, J., Werhahn, J., Wolke, R., Yarwood, G., Zhang, J. H., Rao, S. T., and Galmarini, S.: Model evaluation and ensemble modelling of surface-level ozone in Europe and North America in the context of AQMEII, Atmos. Environ., 53 Special Issue, 60-74, doi:10.1016/j.atmosenv.2012.01.003, 2012.

Solmon, F., Giorgi, F., and Liousse, C.: Aerosol modelling for regional climate studies: application to anthropogenic particles and evaluation over a European/African domain, Tellus B, 58, 51-72, 2006.

Stevenson, D. S., Dentener, F. J., Schultz, M. G., Ellingsen, K., van Noije, T. P. C., Wild, O., Zeng, G., Amann, M., Atherton, C. S., Bell, N., Bergmann, D. J., Bey, I., Butler, T., Cofala, J., Collins, W. J., Derwent, R. G., Doherty, R. M., Drevet, J., Eskes, H. J., Fiore, A. M., Gauss, M., Hauglustaine, D. A., Horowitz, L. W., Isaksen, I. S. A., Krol, M. C., Lamarque, J.-F., Lawrence, M. G., Montanaro, V., Müller, J.-F., Pitari, G., Prather, M. J., Pyle, J. A., Rast, S., Rodriguez, J. M., Sanderson, M. G., Savage, N. H., Shindell, D. T., Strahan, S. E., Sudo, K., and Szopa, S.: Multimodel ensemble simulations of present-day and near-future tropospheric ozone, J. Geophys. Res., 111, D08301, doi:10.1029/2005JD006338, 2006.

Strand, A., and Hov, Ø.: A two-dimensional global study of tropospheric ozone production, J. Geophys. Res., 99, 22877-22895, 1994.

Thomson, A. M., Calvin, K. V., Smith, S. J., Kyle, G. P., Volke, A., Patel, P., Delgado-Arias, S., Bond-Lamberty, B., Wise, M. A., Clarke, L. E., and Edmonds, J. A.: RCP4.5: a pathway for stabilization of radiative forcing by 2100 , Climatic Change, 109 , 77-94, doi:10.1007/s10584-011-0151-4, 2011.

Thunis, P., Rouil, L., Cuvelier, C., Stern, R., Kerschbaumer, A., Bessagnet, B., Schaap, M., Builtjes, P., Tarrason, L., Douros, J., Moussiolopoulos, N., Pirovano, G., and Bedogni, M.: Analysis of model responses to emission-reduction scenarios within the CityDelta project, Atmos. Environ., 41, 208-220, 2007.

Tuovinen, J.-P., Ashmore, M., Emberson, L., and Simpson, D.: Testing and improving the EMEP ozone deposition module, Atmos. Environ., 38, 2373-2385, 2004.

van Loon, M., Vautard, R. Schaap, M. Bergström, R. Bessagnet, B. Brandt, J. Builtjes, P. H. J. Christensen, J. H., Cuvelier, C., Graff, A., Jonson, J. E., Krol, M., Langner, J., Roberts, P., Rouil, L., Stern, R., Tarrason, L., Thunis, P., Vignati, E., White, L., and Wind, P.: Evaluation of long-term ozone simulations from seven regional air quality models, their ensemble, Atmos. Environ., 41, 2083-2097, 2007

Vautard, R., Van Loon, M., Schaap, M., Bergström, R., Bessagnet, B., Brandt, J., Builtjes, P. J. H., Christensen, J. H., Cuvelier, C., Graff, A., Jonson, J. E., Krol, M., Langner, J., Roberts, P., Rouil, L., Stern, R., Tarrason, L., Thunis, P., Vignati, E., White, L., and Wind, P.: Is regional air quality model diversity representative of uncertainty for ozone simulation?, Geophys. Res. Lett., 33, L24818, doi:10.1029/2006GL027610, 2006.

Vautard, R., Builtjes, P. H. J., Thunis, P., Cuvelier, C., Bedogni, M., Bessagnet, B., Honore, C., Moussiopoulos, N., Pirovano, G., Schaap, M., Stern, R., Tarrason, L., and Wind, P.: Evaluation, intercomparison of Ozone, PM10 simulations by several chemistry transport models over four European cities within the CityDelta project, Atmos. Environ., 41, 173-188, 2007. 
Vautard, R., Schaap, M. Bergström, R., Bessagnet, B., Brandt, J., Builtjes, P. J. H., Christensen, J. H., Cuvelier, C., Foltescu, V., Graff, A., Kerschbaumer, A., Krol, M., Roberts, P., Rouïl, L., Stern, R., Tarrason, L., Thunis, P., Vignati, E., and Wind, P.: Skill and uncertainty of a regional air quality model ensemble, Atmos. Environ., 43, 4822-4832, 2009.

Vieno, M., Dore, A. J., Stevenson, D. S., Doherty, R., Heal, M. R., Reis, S., Hallsworth, S., Tarrason, L., Wind, P., Fowler, D., Simpson, D., and Sutton, M. A.: Modelling surface ozone during the 2003 heat-wave in the UK, Atmos. Chem. Phys., 10, 7963-7978, doi:10.5194/acp-10-7963-2010, 2010.

Wesely, M. L.: Parameterization of surface resistance to gaseous dry deposition in regional-scale numerical models, Atmos. Environ., 23, 1293-1304, 1989.

Zaveri, R. and Peters, L. K.: A new lumped structure photochemical mechanism for large-scale applications, J. Geophys. Res., 104, 30387-30415, 1999.
Zhang, L. Moran, M. D., Makar, P. A., Brook, J. R., and Gong, S.: Modelling gaseous dry deposition in AURAMS: a unified regional air-quality modelling system, Atmos. Environ., 36, 537560, 2002.

Zhang, L., Brook, J. R., and Vet, R.: A revised parameterization for gaseous dry deposition in air-quality models, Atmos. Chem. Phys., 3, 2067-2082, doi:10.5194/acp-3-2067-2003, 2003.

Zhang, Y.: Online-coupled meteorology and chemistry models: history, current status, and outlook, Atmos. Chem. Phys., 8, 28952932, doi:10.5194/acp-8-2895-2008, 2008.

Zhang, Y., Wen, X.-Y., and Jang, C. J.: Simulating climatechemistry-aerosol-cloud-radiation feedbacks in continental U.S. using online-coupled WRF/Chem, Atmos. Environ., 44, 35683582, 2010. 